\title{
Piyasa Güven Endeksi ile Finansal Yatırım Araçları Arasındaki İlişki: BRICS ve MIST Ülkeleri Üzerine Bir Araştırma
}

Ferhat Şirin SÖKMEN (https://orcid.org/0000-0002-9563-3526), Şırnak University, Turkey; sokmenferhat@sirnak.edu.tr

Serdar YAMAN (https://orcid.org/0000-0002-8316-0805), Şlrnak University, Turkey; serdaryaman@sirnak.edu.tr

Mert Baran TUNÇEL (https://orcid.org/0000-0001-8554-8080), Şırnak University, Turkey; mbtuncel@sirnak.edu.tr

\section{The Relation Between Business Confidence Index and Financial Investment Instruments: An Investigation on BRICS and MIST Countries}

\begin{abstract}
The relationships between the business confidence index and financial investment instruments were scrutinized for BRICS and MIST countries via panel data analyses in this study. January 2010May 2021 period data of BRICS and MIST countries were utilized within the scope of the study. The long-term cointegration relationships between business confidence index and financial investment instruments were analysed by Westerlund (2007) Panel ECM and Westerlund and Edgerton (2007) Panel LM tests, while Hatemi (2011) asymmetric causality test analysed the causality relationships. According to the panel data analysis results, the effects of investor confidence and expectations on financial investment instruments vary by country.
\end{abstract}

Keywords

$$
\text { Business Confidence Index, Financial Investment Instruments, Panel }
$$
Cointegration, Panel Asymmetric Causality.

JEL Classification Codes : $\quad$ C1, C4, E44.

\section{$\ddot{\mathbf{O} z}$}

Bu çalışmada, piyasa güven endeksi ile finansal yatırım araçları arasındaki ilişkiler BRICS ve MIST ülkeleri için panel veri analizleri ile araştırılmıştır. Çalışmada BRICS ve MIST ülkelerine ait Ocak 2010-Mayıs 2021 dönemi verileri kullanılmıştır. Piyasa güven endeksi ile finansal yatırım araçları arasındaki uzun dönem eşbütünleşme ilişkisi Westerlund (2007) Panel ECM ve Westerlund ve Edgerton (2007) Panel LM testleriyle, nedensellik ilişkisi ise Hatemi (2011) asimetrik nedensellik testiyle analiz edilmiştir. Panel veri analizi sonuçlarına göre, yatırımcı güven ve beklentilerinin finansal yatırım araçlarına olan etkilerinin ülkelere göre farklılık gösterdiği tespit edilmiştir.

Anahtar Sözcükler : Piyasa Güven Endeksi, Finansal Yatırım Araçları, Panel Eşbütünleşme, Panel Asimetrik Nedensellik. 
Sökmen, F.Ş. \& S. Yaman \& M.B. Tunçel (2021), "Piyasa Güven Endeksi ile Finansal Yatırım Araçları Arasındaki İlişki: BRICS ve MIST Ülkeleri Üzerine Bir Araştırma”, Sosyoekonomi, 29(50), 361-386.

\section{Giriş}

Piyasa güven endeksi, sanayi sektöründeki çıktı büyümesini izlemek ve ekonomik faaliyetlerdeki dönüm noktasını takip etmek amacıyla kullanılan bir endekstir (OECD, 2021). Bu tür endeksler hem kamu hem de özel sektörün karar vericilerinin, performanslarını kontrol etmelerine ve politikalarını belirlemelerine yardımcı olmak için kullanılmaktadır (Oral vd., 205: 24). Bunun nedeni; piyasa güven endeksinin, ekonomik faaliyetlerin etkinliğini ve bir bütün olarak ülke ekonomisinin kalkınma hedeflerini karaktarize etmesidir. Bu yönüyle de makroekonomik yapı açısından önem arz etmektedir (Los \& Ocheretin, 2019: 238). Makroekonomik açıdan, güven faktörü, istikrar ortamını yaratarak ekonomik büyümeye katkı sağlarken, mikro düzeyde ise işletmelerin katma değerlerine pozitif etki etmektedir (Kara vd., 2009: 280).

Finansal yatırım araçları ise; yatırım finansmanı ile ilgili kısıtlamaları minimize ederek, yatırımların artmasını sağlamaktadır. Diğer taraftan finansal yatırım araçlarının optimal kullanımı ile birlikte gerçekleşen finansal sistemlerdeki iyileşme, artan üretim talebine yanıt olarak, şirketlerin daha fazla yatırım yapmasına imkân tanımaktadır (Alhaj vd., 2020: 158). Ancak günümüzde yatırımcılar, rasyonellikten uzaklaşmakta ve duygularına göre karar vermektedir. Güven endeksi bu anlamda, rasyonel davranan yatırımcının yerini duygularına göre finansal işlem yapan ve tepkileri net olarak ölçülmeyen yatırımcıya bırakması nedeniyle, yatırımcıların duyarlılığını en iyi yansıtan ölçüt olarak kabul edilmektedir (Beşiktaşlı \& Cihangir, 2020: 55).

Bu çalışmada; piyasa güven endeksi ile finansal yatırım araçları (döviz kurları, devlet tahvilleri ve altın) ilişkisi BRICS (Brezilya, Rusya, Hindistan, Çin ve Güney Afrika) ve MIST (Meksika, Endonezya, Güney Kore ve Türkiye) ülkeleri için ampirik olarak analiz edilmiştir. Çalışmanın ilk iki bölümünde giriş ve literatür yer alırken, üçüncü bölümde kapsam ve veri seti yer almaktadır. Dördüncü bölümde ise analizde kullanılan testlere ilişkin metodoloji ve ampirik analizler sonucunda ulaşılan bulgulara yer verilmiştir. Çalışmanın son bölümünü ise; analizler sonucunda elde edilen bulgulara ilişkin değerlendirmelerin yapıldığı sonuç kısmı oluşturmaktadır.

\section{Literatür Taraması}

Asgary \& Gu (2005), tüketici güven endeksi ile hisse senedi fiyatları arasındaki ilişkiyi ele aldıkları çalışmalarında ABD, İngiltere, Fransa ve Almanya seçili ülkeler olarak incelenmiştir. 1986-2001 yılları arası dikkate alınarak elde edilen sonuçlara göre, ABD, İngiltere ve Fransa için hisse senedi fiyatları ile tüketici güveni arasında ilişki olduğu ortaya konulmuştur.

Bandopadhyaya \& Jones (2006), çalışmalarında 2003-2004 dönemini ele alarak ABD'de güven endeksinin borsa endeksi üzerindeki etkisini incelemişlerdir. Elde edilen analiz sonuçlarına göre, güven endeksinin borsa endeksi üzerinde etkili olduğu tespit edilmiştir. 
Ferreira vd. (2007), çalışmalarında ekonomi güven endeksi ile Avrupa hisse senedi getiri endeksi, Eurostoxx-500 ve FTSE 100 arasındaki ilişkiyi ele almışlardır. 1993-2002 dönemini inceleyen yazarlar güven endeksini açıklamada söz konusu değişkenlerin yetersiz kaldığını tespit etmişlerdir.

Korkmaz \& Çevik (2009), çalışmalarında 1987-2008 dönemi için güven endeksi ile İMKB100 endeks getirisi arasındaki nedensellik ilişkisini incelemişlerdir. Elde edilen analiz sonuçlarına göre, değişkenler arasında çift yönlü etkileşim olduğu tespit edilmiştir.

Hsu vd. (2011), araştırmalarında 1999-2007 yılları arasını inceleyerek tüketici güven endeksleri ile hisse senedi endeksleri arasındaki ilişkiyi tespit etmeye çalışmışlardır. 21 ülkenin ele alındığı çalışmada elde edilen sonuçlara göre, değişkenler arasında eşbütünleşme ilişkisinin olmadığ 1 ancak hisse senedi getirilerinden tüketici güvenine doğru nedensellik olduğu ortaya konmuştur.

Kale \& Akkaya (2016), çalışmalarında tüketici ve reel sektör güven endeksleri ile BIST100, Mali, Sınai, Hizmetler ve Teknoloji endeksleri arasındaki ilişkiyi 2004-2015 dönemi için incelemişlerdir. Elde edilen bulgulara göre, hisse senedi getirilerinden tüketici güven endeksine doğru pozitif yönde nedensellik olduğu tespit edilmiştir.

Eyüboğlu \& Eyüboğlu (2017), çalışmalarında hisse senedi endeksleri ile ekonomi güven endeksi arasındaki ilişkiyi incelemişlerdir. Ocak 2012-Ekim 2016 dönemi için elde edilen analiz sonuçlarına göre, ekonomi güven endeksinden, BIST Ulusal-100, BIST Sınai ve BIST Hizmetler endekslerine doğru nedensellik ilişkisi olduğu tespit edilmiştir.

Güngör (2019), araştırmasında ekonomi güven endeksi ile finansal yatırım araçları arasındaki ilişkiyi incelemiştir. Elde edilen bulgulara göre, Amerikan dolarından elde edilen reel getiri ile ekonomik güven arasında tek yönlü nedensellik ve altından elde edilen reel getiri ile de ekonomik güven arasında tek yönlü nedensellik olduğu tespit edilmiştir.

Evci (2019), araştırmasında ekonomik güven endeksi ile yatırım araçları arasındaki nedensellik ilişkisini incelemiştir. Ocak 2007-Haziran 2019 dönemlerine ilişkin aylık veriler kullanarak elde edilen analiz sonuçlarına göre, BİST100 endeksinin ekonomik güven endeksinin nedeni olmadığı ancak ekonomik güven endeksinin ise BİST100 endeksinin nedeni olduğu tespit edilmiştir. İlaveten USD/TL kuru ile ekonomik güven endeksi arasında tek yönlü nedensellik ilişkisinin olduğu görülürken, ekonomik güven endeksi ile altın fiyatları arasında ise herhangi bir nedensellik ilişkisinin olmadığı tespit edilmiştir.

Barışık \& Dursun (2020), çalışmalarında Türkiye için dolar kuru ve altın fiyatları ile ekonomik güven endeksi arasındaki ilişkiyi ele almışlardır. Çalışma 2007-2019 dönemini kapsamaktadır. Çalışmadan elde edilen bulgulara göre, altın değişkeninden ekonomik güven endeksine ve dolar kuruna doğru kısa dönemli nedensellik; ekonomik güven endeksinden altına ve dolara doğru kısa dönemli nedensellik ilişkisi olduğu belirtilmiştir. Ayrıca değişkenler arasında uzun dönemli ilişkilerin olduğu da tespit edilmiştir. 


\section{Kapsam ve Veri Seti}

Çalışmada BRICS (Brezilya, Rusya, Hindistan, Çin ve Güney Afrika) ve MIST (Meksika, Endonezya, Güney Kore ve Türkiye) ülkelerinde finansal yatırım araçları getirileri ile yatırımcı güven ve beklentileri arasındaki eşbütünleşme ve nedensellik ilişkisi Ocak 2010-Mayıs 2020 dönemi için araştırılmıştır. Çalışma kapsamında finansal yatırım araçları olarak ülkelerdeki temel borsa endeksleri (INDEX), döviz kurları (yerli para birimlerinin ABD doları karşısındaki değeri-CUR), devlet tahvilleri (10 yıllık devlet tahvili faizi-BOND) ve altın (ons altının yerli para birimi cinsinden değeri-GOLD) ele alınmıştır. Çalışmada yatııımcıların ekonomiye ilişkin güven ve beklentileri ise piyasa güven endeksi (business confidence index-BCI) ile temsil edilmiştir. BCI, özellikle sanayi sektörlerindeki üretim, sipariş ve stoklar ile ilgili gelişmeleri dikkate alan anketler sonucunda elde edilen yatırımcı beklentilerini ifade etmektedir. Bu nedenle çalışmanın ilerleyen kısımlarında piyasa güven endeksi ve yatırımcı beklentileri ifadeleri birbirlerinin yerine kullanılmıştır. BCI yatırımcıların ekonomik büyüme ve faaliyetler ile ilgili beklentilerini yansıtmakta olup, 100 'den pozitif yönlü uzaklaşan değerler ilgili dönemlerde yatırımcıların ekonomide yakın gelecekteki iş performansına güvenlerinin artı̆̆ını ifade ederken, 100'den negatif yönlü uzaklaşan değerler ise bu durumun tersini ifade etmektedir (data.oecd.org). Çalışma kapsamında oluşturulan veri setinde yer alan değişkenlere ilişsin bilgiler Tablo 1'de verilmiştir.

\section{Tablo: 1}

\section{Örneklem ve Değişkenlere İlişkin Bilgiler}

\begin{tabular}{|c|c|c|c|c|c|c|}
\hline Ülkeler & $\begin{array}{c}\text { Ülke } \\
\text { Kodu }\end{array}$ & $\begin{array}{l}\text { Yatırımcı } \\
\text { Beklentisi }\end{array}$ & $\begin{array}{l}\text { Temel Borsa Endeksi } \\
\text { (INDEX) }\end{array}$ & $\begin{array}{c}\text { Döviz Kuru } \\
\text { (CUR) }\end{array}$ & $\begin{array}{c}\text { Tahvil } \\
\text { (BOND) }\end{array}$ & $\begin{array}{c}\text { Ons Altın } \\
\text { (GOLD) }\end{array}$ \\
\hline Brezilya & BRA & \multirow{9}{*}{$\mathrm{BCI}$} & Bovespa (BVSP) & USD/BRL & \multirow{9}{*}{10 Y1llık Devlet Tahvili Faizi } & XAU/BRL \\
\hline Rusya & RUS & & MOEX Russia (IMOEX) & USD/RUB & & XAU/RUB \\
\hline Hindistan & IND & & Nifty 50 (NSEI) & USD/INR & & XAU/INR \\
\hline Çin & $\mathrm{CHN}$ & & Shanghai Composite (SSEC) & USD/CNY & & $\mathrm{XAU} / \mathrm{CNY}$ \\
\hline Güney Afrika & $\mathrm{ZAF}$ & & South Africa Top 40 (SA40 - JTOPI) & USD/ZAR & & XAU/ZAR \\
\hline Meksika & MEX & & S\&P/BMV IPC (MXX) & USD/MXN & & XAU/MXN \\
\hline Endonezya & IDN & & IDX Composite (JKSE) & USD/IDR & & XAU/IDR \\
\hline Güney Kore & KOR & & KOSPI (KS11) & USD/KRW & & XAU/KRW \\
\hline Türkiye & TUR & & BIST 100 (XU100) & USD/TRY & & XAU/TRY \\
\hline
\end{tabular}

BRICS ve MIST ülkelerine ilişkin yatırımcı beklentilerini temsil eden BCI değişkenine ilişkin veriler OECD'nin (Organisation for Economic Co-operation and Development) veri tabanı olan data.oecd.org adresinden, finansal yatırım araçlarını temsil eden INDEX, CUR, BOND ve GOLD değişkenlerine ilişkin veriler ise investing.com web adresinden elde edilmiştir. Çalışma dönemi belirlenirken tüm ülkelerde BCI ve finansal yatırım araçlarına ilişkin verilere eksiksiz olarak ulaşılabilen tarihler dikkate alınmış ve bu bağlamda çalışma dönemi Ocak 2010-Mayıs 2020 olarak belirlenmiştir.

Çalışma kapsamında oluşturulan veri seti toplamda 9 birimlik (BRICS ve MIST ülkeleri) yatay kesit boyutuna, 125 dönemlik (Ocak 2010-Mayıs 2020) zaman boyutuna ve her seri için toplamda 1125 gözlem değerine sahip bir panel veri setidir. Çalışmada ilk olarak tüm değişkenlere ilişkin seriler $R_{t}=\ln \left(P_{t} / P_{t-1}\right)$ formülü yardımıyla getiri serisine dönüştürülerek analizlere hazır hale getirilmiştir. Ardından yatırımcı beklentilerindeki 
değişimler ile finansal yatırım araçları getirileri arasındaki ilişkiler panel eş bütünleşme ve panel asimetrik nedensellik analizleri ile incelenmiştir.

\section{Metodoloji ve Bulgular}

Çalışma kapsamında, yatırımcı beklentileri ile finansal yatırım araçları arasındaki ilişkiler modellenirken beş adımlık bir metodolojik süreç izlenmiştir. Birinci adımda, veri setindeki ülkeler arasındaki yatay kesit bağımlılığı (cross-section dependence-CD) Breusch \& Pagan (1980) $L M$, Pesaran (2004) $C D_{L M}$ ve Pesaran, Ullah \& Yagamata (2008) $L M_{a d j}$ testleriyle hem değişken hem de panel bazında kontrol edilmiştir. İkinci adımda, serilere ilişkin eğim katsayılarının homojenlik/heterojenlik durumları Pesaran \& Yagamata (2008) delta $(\tilde{\Delta})$ ve düzeltilmiş delta $\left(\tilde{\Delta}_{a d j}\right)$ testleriyle hem değişken bazında hem de panel bazında incelenmiştir. Üçüncü adımda, serilerin durağanlık durumları, Bai \& Ng (2004) Panel Analysis of Nonstationarity in Idiosyncratic and Common Components (PANIC), Pesaran (2007) Cross-sectionally Augmented Dickey Fuller (CADF) ve Cross-sectionally Augmented IPS (CIPS) ve Hadri \& Kurozumi (2012) HK testleri ile incelenmiştir. Dördüncü adımda yatırımcı beklentileri ile finansal yatırım araçları arasındaki uzun dönem eşbütünleşme ilişkisi Westerlund (2007) Panel Error Correction Model (ECM) ve Westerlund \& Edgerton (2007) Panel Lagrange Multiplier (LM) testleri ile incelenmiştir. Son olarak beşinci adımda, seriler arasındaki asimetrik nedensellik ilişkisi Hatemi (2011) asimetrik nedensellik testi ile incelenmiştir. Ekonometrik analizlere geçilmeden önce serilere ilişkin tanımlayıcı istatistikler ve seriler arasındaki korelasyon Tablo 2 yardımıyla incelenmiştir.

Tablo: 2

Tanımlayıcı İstatistikler ve Spearman Korelasyon Analizi

\begin{tabular}{|c|c|c|c|c|c|}
\hline \multicolumn{6}{|c|}{ Tanımlayıcı İstatistikler } \\
\hline & BCI & INDEX & CUR & BOND & GOLD \\
\hline Ortalama & $-0,000337$ & 0,003247 & 0,005427 & $-0,003072$ & 0,009070 \\
\hline Medyan & $-0,000258$ & 0,006369 & 0,001254 & $-0,005685$ & 0,005515 \\
\hline Maksimum & 0,021690 & 0,187058 & 0,210128 & 0,283668 & 0,203236 \\
\hline Minimum & $-0,043499$ & $-0,355309$ & $-0,130417$ & $-0,210530$ & $-0,129691$ \\
\hline Standart Sapma & 0,003763 & 0,051515 & 0,029871 & 0,054639 & 0,050762 \\
\hline Çarpıklık & $-2,896328$ & $-0,633939$ & 1,108458 & 0,531134 & 0,374767 \\
\hline Basıklık & 37,43935 & 6,511162 & 8,864022 & 5,638566 & 3,398399 \\
\hline J-B İstatistik & 57169,85 & 653,2392 & 1842,257 & 379,2395 & 33,77457 \\
\hline J-B Olasılık & $0,001 * * *$ & 0,001 *** & $0,001 * * *$ & $0,001^{* * *}$ & $0,001^{* * *}$ \\
\hline Gözlem & 1125 & 1125 & 1125 & 1125 & 1125 \\
\hline \multicolumn{6}{|c|}{ Spearman Korelasyon Analizi } \\
\hline & BCI & INDEX & CUR & BOND & GOLD \\
\hline \multirow[t]{2}{*}{ BCI } & 1,000000 & & & & \\
\hline & ------ & & & & \\
\hline \multirow[t]{2}{*}{ INDEX } & 0,157810 & 1,000000 & & & \\
\hline & $(0,001)$ & ----- & & & \\
\hline \multirow[t]{2}{*}{ CUR } & $-0,241749$ & $-0,299200$ & 1,000000 & & \\
\hline & $(0,001)$ & $(0,001)$ & ------ & & \\
\hline \multirow[t]{2}{*}{ BOND } & $-0,021313$ & $-0,280383$ & 0,303159 & 1,000000 & \\
\hline & $(0,4751)$ & $(0,001)$ & $(0,001)$ & ------ & \\
\hline \multirow[t]{2}{*}{ GOLD } & $-0,161741$ & $-0,042237$ & 0,461525 & $-0,045366$ & 1,000000 \\
\hline & $(0,001)$ & $(0,1569)$ & $(0,001)$ & $(0,1283)$ & ----- \\
\hline
\end{tabular}


Sökmen, F.Ş. \& S. Yaman \& M.B. Tunçel (2021), "Piyasa Güven Endeksi ile Finansal Yatırım Araçları Arasındaki İlişki: BRICS ve MIST Ülkeleri Üzerine Bir Araştırma”, Sosyoekonomi, 29(50), 361-386.

Tablo 2'de yer alan tanımlayıcı istatistikler incelendiğinde BCI ve BOND serilerine ilişkin ortalama değerlerin negatif olduğu, buna karşın INDEX, CUR ve GOLD serilerine ilişkin ortalama değerlerin ise pozitif olduğu görülmektedir. Söz konusu değerler BRICS ve MIST ülkelerinde ilgili dönemde yatırımcı beklentilerinin ve 10 yıllık devlet tahvili faiz getirilerinin negatif ortalama değere sahip olduğu, ülkelerdeki temel borsa endeksi getirileri, döviz kuru getirileri ve ons altın getirilerinin ise pozitif ortalama değere sahip olduğunu göstermektedir. Serilere ilişkin standart sapma değerleri incelendiğinde, BOND serisinin en yüksek standart sapma değerine, BCI serisinin ise en düşük standart sapma değerine sahip olduğu görülmektedir. Standart sapma değerleri, ilgili dönemde ülkelerdeki piyasa güven endekslerinde düşük düzeyde değişimlerin yaşandığı, buna karşın özellikle 10 yıllık devlet tahvili faiz getirileri ve borsa endeksleri getirilerinde ise nispeten yüksek düzeyde değişimler gözlendiğini ortaya koymaktadır. Serilere ilişkin çarpıklık değerleri incelendiğinde, BCI ve INDEX serilerinin sola çarpık, CUR, BOND ve GOLD serilerinin ise sağa çarpık olduğu; basıklık değerleri incelendiğinde ise, tüm serilerin pozitif basıklık değerlerine sahip olduğu ve dolayısıyla sivri dağılıma sahip olduğu görülmektedir. Jargue-Bera (J-B) olasılık değerinin tüm seriler için 0.05 'ten düşük olduğu ve serilerin normal dağılıma uyum sağlamadığı görülmektedir. Serilere ilişkin çarpıklık ve basıklık değerlerinin 0'a eşit olmaması ve ortalama ve medyan değerlerinin çakışık olmaması da serilerin normal dağılıma uyum sağlamadıklarını göstererek J-B test istatistiğini desteklemektedir (Çil Yavuz, 2015: 34-37). Bu anlamda serilerin klasik finans serileri şeklinde hareket ettikleri söylenebilir.

Tablo 2'de yer alan Spearman Korelasyon analizi sonuçlarına göre, BCI serisi ile INDEX, CUR ve GOLD serileri arasında \%5 anlamlılık düzeyinde istatistiksel olarak anlamlı ilişkilerin bulunduğu tespit edilmiştir. Bu durum özellikle INDEX, CUR ve GOLD serileri ile BCI serileri arasında uzun dönemli eşbütünleşme ve nedensellik ilişkilerinin de bulunabileceğine işaret etmektedir.

\subsection{Yatay Kesit Bağımlılığı}

Yüksek düzeyde küreselleşme ve uluslararası ticaret ve finansal entegrasyon nedeniyle bir ülkeyi etkileyen bir şok, benzer niteliklere sahip diğer ülkeleri de etkileyebilmektedir (Menyah vd., 2014: 389). Söz konusu durum yatay kesit bağımlılı̆̆1 olarak adlandırılmaktadır. Veri setinde yer alan bir serideki birimler arasında gözlemlenen yatay kesit bağımlılığı, seriye ilişkin analiz sonuçlarını önemli ölçüde etkileyebilmektedir (De Hoyos \& Safaridis, 2016: 482-483). Serilerde yatay kesit bağımlılığının bulunup bulunmamasına göre uygulanacak birim kök testleri, eşbütünleşme testleri ve nedensellik testleri değişiklik gösterebilmektedir. Bu durum panel veri analizlerinde tahminleme yapmadan önce yatay kesit bağımlılığının test edilmesini gerekli kılmaktadır. Yatay kesit bağımlılığının test edilmesi için birçok test bulunmakla birlikte bu çalışmada, literatürde sıklıkla kullanılan ve çalışmanın veri setinin niteliklerine uygun olan testler olan Breusch \& Pagan (1980) $L M$, Pesaran (2004) $C D_{L M}$ ve Pesaran, Ullah \& Yagamata (2008) $L M_{a d j}$ testleri ile yatay kesit bağımlılığı test edilmiştir. $L M$ test istatistiği denklem (1) ile hesaplanmaktadır (Breusch \& Pagan, 1980: 247). 


$$
L M=T \sum_{i=1}^{N-1} \sum_{j=i+1}^{N} \hat{\rho}_{i j}^{2}
$$

Denklem (1)'de $T$ zaman boyutunu, $N$ yatay kesit boyutunu, $\hat{\rho}$ ise bireysel en küçük kareler tahmininden elde edilen hata terimlerinin ikili korelasyon katsayısını ifade etmektedir. $L M$ testi $N$ 'in nispeten küçük $T$ 'nin ise büyük olduğu $(\mathrm{T}>\mathrm{N})$, diğer bir ifadeyle $\mathrm{N}$ sabit ve $\mathrm{T} \rightarrow \infty$ olan paneller için uygundur (Ozcan vd., 2017: 84).

$L M$ testine alternatif olarak Pesaran tarafından 2004 yılında geliştirilen $C D_{L M}$ testi ise, hem $\mathrm{N} \rightarrow \infty$ hem de $\mathrm{T} \rightarrow \infty$ olması durumunda uygun bir yatay kesit bağımlılı̆̆ testidir. $C D_{L M}$ test istatistiği denklem (2) ile hesaplanmaktadır (Pesaran, 2004: 5).

$$
C D_{L M}=\sqrt{\left(\frac{1}{N(N-1)}\right)} \sum_{i=1}^{N-1} \sum_{j=i+1}^{N}\left(T \hat{\rho}_{i j}^{2}-1\right)
$$

T'nin büyük ve N'in küçük $(\mathrm{T}>\mathrm{N})$ olduğu durumlarda kullanılan bir diğer alternatif test ise Pesaran vd., (2008) tarafından geliştirilen $L M_{a d j}$ testidir. $L M_{a d j}$ testi, $L M$ istatistiğinin ortalamasını ve varyansını kullanarak $L M$ testinin değiştirilmiş bir versiyonu olan ve $C D_{L M}$ testindeki korelasyon toplamlarının 0 (sıfır) olma olasılığını ortadan kaldıran bir yatay kesit bağımlılı̆̆ testidir (Menyah vd., 2014: 390). $L M_{a d j}$ test istatistiği denklem (3) ile hesaplanmaktadır (Pesaran vd., 2008: 108).

$$
L M_{a d j}=\sqrt{\left(\frac{2}{N(N-1)}\right)} \sum_{i=1}^{N-1} \sum_{j=i+1}^{N} \hat{\rho}_{i j} \frac{(T-k) \rho_{i j}^{2}-\mu_{T i j}}{\sqrt{v_{T i j}^{2}}}
$$

Denklem (3)'te $k$ açıklayıcı değişken sayısını, $\mu_{T i j}$ ve $v_{T i j}^{2}$ ise sırasıyla $(T-k) \rho_{i j}^{2}$ 'ya ilişkin ortalamayı ve varyansı ifade etmektedir. $L M, C D_{L M}$ ve $L M_{a d j}$ testleri $\mathrm{T}>\mathrm{N}$ varsayımını dikkate alan testler oldukları için çalışmada yatay kesit bağımlılığı incelemesinde kullanılmışlardır. Her üç test de seride yatay kesit bağımlılığının olmadığı, temel hipotez ile test edilmektedir. Serilere ve modellere ilişkin $L M, C D_{L M}$ ve $L M_{a d j}$ test sonuçları Tablo 3 'te yer almaktadır. Tablo 3 'te yer alan Model 1 INDEX serisinin bağımlı, BCI serisinin bağımsız değişken; Model 2 CUR serisinin bağımlı, BCI serisinin bağımsız değişken; Model 3 BOND serisinin bağıml, BCI serisinin bağımsız değişken ve Model 4 ise GOLD serisinin bağımlı, BCI serisinin bağımsız değişken olduğu ekonometrik modelleri ifade etmektedir.

Tablo 3'te verilen $L M$ ve $C D_{L M}$ test sonuçları incelendiğinde, tüm seriler için hem sabit hem de sabit ve trendli modelde $\% 1$ anlamlılık düzeyinde $(\mathrm{p}<0.01) \mathrm{H}_{0}$ hipotezi reddedilmektedir. Dolayısıyla her iki test sonucuna göre de serilerde yatay kesit bağımlılığı tespit edilmiştir. $L M_{a d j}$ test sonucuna göre de BCI serisi sabit modelde $\% 10$ ve sabit ve trendli modelde $\% 5$ anlamlılık düzeyinde; INDEX, CUR ve GOLD serileri hem sabit hem de sabit ve trendli modellerde $\% 1$ anlamlılık düzeyinde anlamlı olduğu, BOND serisi ise, hem sabit hem de sabit ve trendli modelde $\% 10$ anlamlılık düzeyinde anlamlı olmadığ 1 belirlenmiştir. Yatay kesit test sonuçlarının BCI, INDEX, CUR ve GOLD serileri için genel anlamda tutarlı sonuçlar verdiği, BOND serisi özelinde ise $L M_{a d j}$ test sonuçları ile $L M$ ve $C D_{L M}$ test sonuçlarının çeliştiği gözlemlenmiştir. BOND serisine ilişkin $L M$ ve $C D_{L M}$ test sonuçlarının 
serinin yatay kesit bağımlılığı içerdiğine yönelik bulgular suması nedeniyle serinin yatay kesit bağımlılı̆̆ içerdiğine kanaat getirilmiştir.

Tablo: 3

\section{Yatay Kesit Bağımlılığı Testleri Sonuçları}

\begin{tabular}{|c|c|c|c|c|c|c|c|c|c|c|c|c|}
\hline \multirow{3}{*}{$\begin{array}{l}\text { CD Test } \\
\text { Değgişkenler }\end{array}$} & \multicolumn{6}{|c|}{ Sabit Model } & \multicolumn{6}{|c|}{ Sabit ve Trendli Model } \\
\hline & \multicolumn{2}{|c|}{$L M$} & \multicolumn{2}{|c|}{$C D_{L M}$} & \multicolumn{2}{|c|}{$\boldsymbol{L} \boldsymbol{M}_{a d j}$} & \multicolumn{2}{|c|}{$L M$} & \multicolumn{2}{|c|}{$C D_{L M}$} & \multicolumn{2}{|c|}{$L M_{a d j}$} \\
\hline & İstat. & p & \begin{tabular}{|l|} 
İstat. \\
\end{tabular} & p & İstat. & p & İstat. & p & İstat. & p & İstat. & p \\
\hline BCI & 172,042 & $0,001 * * *$ & 16,033 & $0,001 * * *$ & 1,437 & $0,075^{*}$ & 170,466 & $0,001^{*} * *$ & 15,847 & 0,001 *** $*$ & 2,108 & $0,018^{* *}$ \\
\hline INDEX & 123,204 & $0,001 * * *$ & 10,277 & $0,001 * * *$ & 4,701 & $0,001 * * *$ & 122,243 & $0,001^{* * *}$ & 10,164 & $0,001^{* * *}$ & 4,863 & $0,001 * * *$ \\
\hline CUR & 93,860 & $0,001 * * *$ & 6,819 & $0,001 * * *$ & 5,834 & 0,001 *** & 94,575 & $0,001 * * *$ & 6,903 & 0,001 *** & 6,600 & $0,001 * * *$ \\
\hline BOND & 144,416 & $0,001 * * *$ & 12,777 & $0,001 * * *$ & 1,131 & 0,129 & 144,009 & $0,001 * * *$ & 12,729 & $0,001 * * *$ & 0,586 & 0,279 \\
\hline GOLD & 171,499 & $0,001 * * *$ & 15,969 & $0,001 * * *$ & 10,814 & $0,001 * * *$ & 172,974 & $0,001^{* * *}$ & 16,143 & $0,001 * * *$ & 9,215 & $0,001 * * *$ \\
\hline CD Test & \multicolumn{4}{|c|}{$L M$} & \multicolumn{4}{|c|}{$C D_{L M}$} & \multicolumn{4}{|c|}{$\boldsymbol{L M}_{a d j}$} \\
\hline Modeller & & İstatistik & \multicolumn{2}{|l|}{$\mathbf{p}$} & & İstatistik & \multicolumn{2}{|l|}{$\mathbf{p}$} & & İstatistik & \multicolumn{2}{|l|}{ p } \\
\hline MODEL 1 & & 61,228 & \multicolumn{2}{|l|}{$0,001 * * *$} & & 4,440 & \multicolumn{2}{|l|}{$0,001 * * *$} & & 4,515 & \multicolumn{2}{|c|}{$0,001 * * *$} \\
\hline MODEL 2 & & 47,115 & \multicolumn{2}{|l|}{$0,013^{* *}$} & & 2,554 & \multicolumn{2}{|l|}{$0,005^{* * * *}$} & & 2,566 & \multicolumn{2}{|c|}{$0,005^{* * * * * ⿰ ㇇ ⿰ 亅 ⿱ 丿 丶 丶 ~}$} \\
\hline MODEL 3 & & 75,954 & \multicolumn{2}{|l|}{$0,001 * * *$} & & 6,408 & \multicolumn{2}{|l|}{$0,001^{* * * *}$} & & 6,485 & \multicolumn{2}{|c|}{$0,001 * * *$} \\
\hline MODEL 4 & & 69,846 & \multicolumn{2}{|l|}{$0,001^{* * * *}$} & & 5,592 & \multicolumn{2}{|l|}{0,001 **** $*$ * } & & 5,647 & \multicolumn{2}{|c|}{$0,001 * * *$} \\
\hline
\end{tabular}

Panel bazında yatay kesit bağımlılığı analizleri sonucunda, modellere ait $L M, C D_{L M}$ ve $L M_{a d j}$ olasılık değerlerinin $\% 1$ ve $\% 5$ anlamlılık düzeylerinde anlamlı olduğu ve tüm modeller için panel bazında yatay kesit bağımlılı̆̆ının olmadığını ifade eden $\mathrm{H}_{0}$ hipotezinin reddedildiği, dolayısıyla modellerde panel bazında yatay kesit bağımlılığının var olduğu tespit edilmiştir.

\subsection{Homojenite/Heterojenite}

Serilere ilişkin uygun birim kök testleri ve tahmin edilecek modellere ilişkin uygun eşbütünleşme ve nedensellik testleri seçiminde dikkate alınan diğer bir unsur da serilerde ve modellerde eğim katsayılarının homojenlik/heterojenlik durumlarıdır. Çalışmada serilerde ve modellerde eğim katsayılarının homojenlik/heterojenlik durumları Pesaran \& Yagamata (2008) tarafından geliştirilen $\tilde{\Delta}$ ve $\tilde{\Delta}_{a d j}$ testleriyle incelenmiştir. $\tilde{\Delta}$ ve $\tilde{\Delta}_{a d j}$ test istatistikleri denklem (4) ve (5) ile hesaplanmaktadır (Pesaran \& Yagamata, 2008: 57).

$$
\begin{aligned}
& \tilde{\Delta}=\sqrt{N}\left(\frac{N^{-1} \tilde{S}-k}{\sqrt{2 K}}\right) \\
& \tilde{\Delta}_{a d j}=\sqrt{N}\left(\frac{N^{-1} \tilde{S}-E\left(\tilde{Z}_{i t}\right)}{\sqrt{\operatorname{Var}\left(\tilde{Z}_{i t}\right)}}\right)
\end{aligned}
$$

Denklem (4) ve (5)'te $\tilde{S}$ düzeltilmiş Swamy istatistiğini, $\tilde{Z}_{i t}$ sınırlı ortalama varyansa sahip rastgele bağımsız değişkenleri, $E\left(\tilde{Z}_{i t}\right) k^{\prime}$ yı, $\operatorname{Var}\left(\tilde{z}_{i t}\right)$ ise $2 k(T-K-1) / T+1$ 'i ifade etmektedir (Demir \& Görür, 2020: 20). Her iki test istatistiği de eğim katsayılarının homojenliğini temel hipotez ile test etmektedir. Serilere ve modellere ilişkin $\tilde{\Delta}$ ve $\tilde{\Delta}_{a d j}$ testleri sonuçları Tablo 4'te yer almaktadır.

Tablo 4'te yer alan homojenite testleri sonuçları incelendiğinde, BCI ve CUR serileri, Model 2 ve Model 4 olasılık değerlerine göre $(\mathrm{p}<0.01) \mathrm{H}_{0}$ hipotezleri reddedilerek her iki 
teste göre de $\% 1$ anlamlılık düzeyinde BCI ve CUR serileri ve Model 2 ve Model 4 için eğim katsayılarının heterojen olduğu söylenebilir. INDEX, BOND ve GOLD serileri, Model 1 ve Model 3 olasılık değerlerine göre $(\mathrm{p}>0.01)$ ise $\mathrm{H}_{0}$ hipotezleri kabul edilerek her iki teste göre de $\% 1$ anlamlılık düzeyinde INDEX, BOND ve GOLD serileri, Model 1 ve Model 3 eğim katsayılarının homojen olduğu söylenebilir.

Tablo: 4

Homojenite Testleri Sonuçları

\begin{tabular}{|c|c|c|c|c|}
\hline \multirow{2}{*}{ Değişkenler } & \multicolumn{2}{|c|}{$\widehat{\Delta}$} & \multicolumn{2}{|c|}{$\widehat{\Delta}_{a d j}$} \\
\hline & İstatistik & $\mathbf{p}$ & İstatistik & $\mathbf{p}$ \\
\hline BCI & 5,421 & $0,001 * * *$ & 5,487 & $0,001 * * *$ \\
\hline INDEX & 0,885 & 0,188 & 0,895 & 0,185 \\
\hline CUR & 3,792 & $0,001 * * *$ & 3,838 & $0,001 * * *$ \\
\hline BOND & 0,375 & 0,354 & 0,379 & 0,352 \\
\hline GOLD & $-0,062$ & 0,525 & $-0,063$ & 0,525 \\
\hline MODEL 1 & 0,276 & 0,391 & 0,279 & 0,390 \\
\hline MODEL 2 & 7,952 & $0,001 * * *$ & 8,049 & $0,001 * * *$ \\
\hline MODEL 3 & $-0,347$ & 0,636 & $-0,352$ & 0,637 \\
\hline MODEL 4 & 3,494 & $0,001 * * *$ & 3,537 & $0,001 * * *$ \\
\hline
\end{tabular}

\subsection{Panel Birim Kök Analizi}

Panel veri analizlerinde tahminleme yapılmadan önce gerçekleştirilmesi gereken ön testlerden biri de birim kök testleridir. Bir serinin durağan olması (birim kök içermemesi) en genel anlamda, ilgili seriye ait ortalama, varyans ve kovaryansın hangi düzeyde ölçülürse ölçülsün sabit kalması ve seriye ait iki değer arasındaki farkın sadece iki zaman değeri arasındaki farka bağlı olması şeklinde ifade edilebilir (Gujarati, 2004: 798). Durağan olmayan serilerde (birim kök içeren serilerde) ise, uzun dönemde ortalama sabit bir değer bulunmamakta, zaman sonsuza gittikçe varyans da sonsuza gitmektedir. Panel veri analizinde birim kök sınaması yapılırken yatay kesit bağımlılığını dikkate almayan (birinci nesil) birim kök testleri ve yatay kesit bağımlılığını dikkate alan (ikinci nesil) birim kök testleri kullanılabilmektedir. Bu çalışmada veri setini oluşturan serilerin yatay kesit bağımlılı̆̆ içermesi nedeniyle serilerde durağanlık ikinci nesil birim kök testlerinden olan Bai \& Ng (2004) PANIC, Pesaran (2007) CADF ve CIPS ve Hadri \& Kurozumi (2012) HK testleri ile incelenmiştir.

PANIC testi, birinci nesil birim kök testlerinden olan Maddala \& Wu (1999) Fisher ADF ve Choi (2001) Fisher PP testlerinin yatay bağımlılığını dikkate alacak şekilde tasarlanması ve $\mathrm{N} \rightarrow \infty$ için geliştirilmesi şekilde oluşturulmuştur (Bai \& Ng, 2004: 1140). PANIC testi sonucunda Maddala \& Wu (1999) Fisher ADF test istatistiğine dayanan $P_{\hat{e}}^{\tau}$ ve Choi (2001) Fisher PP test istatistiğine dayanan $P_{\hat{e}}^{c}$ test istatistikleri elde edilmektedir. Bu bağlamda PANIC birim kök testinin genel gösterimi denklem (6) ve denklem (7) de verilmiştir (Bai \& Ng, 2004: 1140).

$$
P_{\hat{e}}^{C}=\frac{-2 \sum_{i=1}^{N} \log p_{\hat{e}}^{c}(i)-2 N}{\sqrt{4 N}} \stackrel{d}{\rightarrow} N(0,1)
$$




$$
P_{\hat{e}}^{\tau}=\frac{-2 \sum_{i=1}^{N} \log p_{\hat{e}}^{\tau}(i)-2 N}{\sqrt{4 N}} \stackrel{d}{\rightarrow} N(0,1)
$$

CADF testinde, birimlere ilişkin serilerin birinci farkları ve gecikmeli düzeyleri kullanılarak yatay kesit ortalaması ile ADF regresyon modeli genişletilmekte ve böylece birimler arasındaki bağımlılık yok edilmektedir. Teste ilişkin regresyon modeli denklem (8)'deki gibidir.

$$
\Delta y_{i t}=a_{i}+b_{i} y_{i, t-1}+c_{i} \bar{y}_{t-1}+d_{i} \Delta \bar{y}_{t}+e_{i t}
$$

Denklem (8)'de, $t$ zamanı, $e_{i t}$ birimlere özgü hatayı, $a_{i}, b_{i}$ ve $c_{i}$ sabit etki katsayılarını, $\bar{y}_{t}$ tüm gözlemlerin $t$ zamandaki ortalamasını, $y_{i}$ ise belirli bir yoğunluk fonksiyonuna sahip başlangıç değerlerini göstermektedir (Demir \& Görür, 2020: 23). CADF değeri her bir birim için ayrı ayrı hesaplandığından CADF test istatistiği birim bazında durağanlık sınaması için kullanılmaktadır. CIPS test istatistiği ise denklem (9)'da gösterildiği gibi CADF istatistik değerlerinin aritmetik ortalaması alınarak hesaplanmakta ve panel bazında durağanlık sınaması için kullanılmaktadır.

$$
C I P S=\frac{1}{N} \sum_{i=1}^{N} C A D F_{i}
$$

Hesaplanan CADF ve CIPS değerleri Pesaran (2007) çalışmasında yer alan tablo değerleri ile karşılaştırılarak serilerin durağanlıkları üzerine karar verilmektedir. Hesaplanan test istatistiğinin belirli bir anlamlılık düzeyi için verilen kritik değerden düşük olması ilgili anlamlılık düzeyinde serinin durağan olduğuna işaret etmektedir (Pesaran, 2007: 274-281).

Çalışmada serilerin durağanlıklarını sınamak için kullanılan diğer bir birim kök testi ise Hadri \& Kurozumi (2012) testidir. Bu test Pesaran (2007) CADF ve CIPS testinden ilham alınarak KPSS tekniğiyle geliştirilmiş bir birim kök testidir. Test sonucunda $Z_{A}^{S P C}$ ve $Z_{A}^{L A}$ olmak üzere iki ayrı test istatistiği elde edilir. $Z_{A}^{S P C}$ test istatistiği Sul, Phillips \& Choi (2005) testine benzer şekilde $\operatorname{AR}(\mathrm{p}), Z_{A}^{L A}$ test istatistiği ise Choi (1993) ve Toda \& Yamamoto (1995) testindeki gibi AR(p+1) süreçlerini dikkate almaktadır. Söz konusu test istatistikleri CADF test istatistiğinin zayıf kalması durumunda bir sağlam nitelinde olup sahte birim kökün ortaya çıkmasını engellemektedir (Yücesan \& Yağış, 2020: 700). Hadri \& Kurozumi (2012) için oluşturulan eşitlik, denklem (10)'daki gibidir.

$$
y_{i t}=Z_{t}^{\prime} \delta_{i}+f_{t} \gamma_{i}+\varepsilon_{i t} \varepsilon_{i t}=\phi_{i 1} \varepsilon_{i t-1}+\cdots+\phi_{i p} \varepsilon_{i t-p}+v_{i t}
$$

Denklem (10)'da $Z_{t}^{\prime}$ deterministiktir ve bağımlı değişkendeki değişimleri açıklayabilmektedir. $Z_{A}^{S P C}$ ve $Z_{A}^{L A}$ test istatistikleri denklem (11) ve denklem (12)'deki gibi hesaplanmaktadır.

$$
\begin{aligned}
& Z_{A}^{S P C}=\frac{1}{\hat{\sigma}_{S P C}^{2} T^{2}} \sum_{t=1}^{T}\left(S_{i t}^{W}\right)^{2} \\
& Z_{A}^{L A}=\frac{1}{\widehat{\sigma}_{L A}^{2} T^{2}} \sum_{t=1}^{T}\left(S_{i t}^{W}\right)^{2}
\end{aligned}
$$


Çalışma kapsamında kullanılan birim kök testlerinden PANIC ve CADF ve CIPS testleri serilerin durağan olmadıklarını ifade eden temel hipotezi sınarken, HK testi ise serilerin durağan olduğunu ifade eden temel hipotezi sınamaktadır. PANIC, CADF ile CIPS ve HK testlerine ilişkin sonuçlar sırasıyla Tablo 5, Tablo 6 ve Tablo 7'de verilmiştir.

Tablo: 5

Bai \& Ng (2004) PANIC Birim Kök Testi

\begin{tabular}{|c|c|c|c|c|c|c|c|c|}
\hline \multirow{3}{*}{ Değişkenler } & \multicolumn{4}{|c|}{ Sabit Model } & \multicolumn{4}{|c|}{ Sabit ve Trendli Model } \\
\hline & \multicolumn{2}{|c|}{$\boldsymbol{P}_{\hat{e}}^{c}$} & \multicolumn{2}{|c|}{$\boldsymbol{P}_{\hat{e}}^{\tau}$} & \multicolumn{2}{|c|}{$\boldsymbol{P}_{\hat{e}}^{c}$} & \multicolumn{2}{|c|}{$\boldsymbol{P}_{\hat{e}}^{\tau}$} \\
\hline & İstatistik & $\mathbf{p}$ & İstatistik & p & İstatistik & p & İstatistik & $\mathbf{p}$ \\
\hline BCI & $-1,8920$ & 0,9708 & 6,6483 & 0,9928 & $-2,1018$ & 0,9822 & 5,3892 & 0,9981 \\
\hline INDEX & $-1,4676$ & 0,9289 & 9,1947 & 0,9551 & $-1,0127$ & 0,8444 & 11,9241 & 0,8511 \\
\hline CUR & $-2,6188$ & 0,9956 & 2,2874 & 1,0000 & $-1,7191$ & 0,9572 & 7,6856 & 0,9830 \\
\hline BOND & $-0,7697$ & 0,7793 & 13,3818 & 0,7684 & $-1,2118$ & 0,8872 & 10,7289 & 0,9055 \\
\hline GOLD & $-2,5722$ & 0,9949 & 2,5670 & 1,0000 & $-1,2754$ & 0,8989 & 10,3477 & 0,9200 \\
\hline \multirow{3}{*}{ Değişkenler } & \multicolumn{4}{|c|}{ Sabit Model } & \multicolumn{4}{|c|}{ Sabit ve Trendli Model } \\
\hline & \multicolumn{2}{|c|}{$\boldsymbol{P}_{\hat{\mathrm{e}}}^{c}$} & \multicolumn{2}{|c|}{$P_{\hat{e}}^{\tau}$} & \multicolumn{2}{|c|}{$P_{\hat{e}}^{c}$} & \multicolumn{2}{|c|}{$\boldsymbol{P}_{\hat{e}}^{\tau}$} \\
\hline & İstatistik & $\mathbf{p}$ & İstatistik & p & İstatistik & Olasılık & İstatistik & p \\
\hline D(BCI) & 6,8503 & $0,001^{* * * *}$ & 59,1018 & $0,001 * * *$ & 5,6913 & $0,001 * * * *$ & 52,1476 & $0,001^{* * * *}$ \\
\hline D(INDEX) & 9,0000 & $0,001^{* * * *}$ & 72,0000 & $0,001 * * *$ & 9,0000 & $0,001 * * *$ & 72,0000 & 0,001 **** \\
\hline D(CUR) & 9,0000 & $0,001 * * *$ & 72,0000 & $0,001 * * *$ & 9,0000 & $0,001 * * *$ & 72,0000 & 0,001 *** \\
\hline D(BOND) & 9,0000 & $0,001 * * *$ & 72,0000 & $0,001 * * *$ & 9,0000 & 0,001 **** & 72,0000 & 0,001 **** \\
\hline D(GOLD) & 9,0000 & $0,001^{* * *}$ & 72,0000 & $0,001^{* * * *}$ & 9,0000 & $0,001 * * *$ & 72,0000 & $0,001^{* * * *}$ \\
\hline
\end{tabular}

Tablo 5'e göre, düzeyde tüm serilere ilişkin hem sabit hem de sabit ve trendli modellerde $P_{\hat{e}}^{c}$ ve $P_{\hat{e}}^{\tau}$ olasilık değerlerinin $\% 10, \% 5$ ve $\% 1$ anlamlllık düzeylerinde (sırasiyla $\mathrm{p}>0.1, \mathrm{p}>0.05$ ve $\mathrm{p}>0.01)$ anlamlı olmadığı tespit edilmiş, dolayısıyla tüm seriler için serinin durağan olmadığını ifade eden $\mathrm{H}_{0}$ hipotezi reddedilememiştir. Birinci farklarında ise serilere ilişkin hem sabit hem de sabit ve trendli modellerde $P_{\hat{e}}^{c}$ ve $P_{\hat{e}}^{\tau}$ olasılık değerlerinin $\% 1$ anlamlılık düzeyinde $(\mathrm{p}<0.01)$ anlamlı olduğu tespit edilmiş, dolayısıyla tüm seriler için serinin durağan olmadığını ifade eden $\mathrm{H}_{0}$ hipotezi reddedilmiştir.

Tablo 6'da yer alan CIPS test sonuçları, düzeyde sabitli modelde BCI serisine ilişkin test istatistik değerinin $\% 5$ anlamlılık düzeyinde anlamlı olduğu tespit edilmiş ve sabitli modelde BCI serisinin durağan olmadığını ifade eden $\mathrm{H}_{0}$ hipotezi reddedilmiştir. Düzeyde BCI serisine ilişkin sabitli ve trendli model test istatistik değerinin ve INDEX, CUR, BOND ve GOLD serilerine ilişkin ise hem sabitli hem trendli model test istatistik değerlerinin tüm anlamlılık düzeylerinde anlamsız olduğu tespit edilmiş ve serilerin durağan olmadıklarını ifade eden $\mathrm{H}_{0}$ hipotezi reddedilememiştir. Tüm serilerin birinci farklarına ilişkin CIPS istatistikleri ise $\% 1$ anlamlılık düzeyinde anlamlı olarak elde edilmiş ve serilerin durağan olmadıklarını ifade eden $\mathrm{H}_{0}$ hipotezi reddedilmiştir. Sonuçlar doğrultusunda panel bazında serilerin düzeyde durağan olmadığı, birinci farklarında ise durağan olduğu tespit edilmiştir. CADF test istatistikleri incelendiğinde, düzeyde serilere ilişkin istatistik değerlerinin sabitli ve sabitli ve trendli modellerde farklı ülkelerde farklı anlamlılık düzeylerinde farklı sonuçlar verdiği gözlemlenmiştir. Sonuçlar, serilerin ülkelerin büyük çoğunluğunda düzeyde durağan olmadıklarını işaret etmektedir. Serilerin birinci farklarına ilişkin CADF test istatistik değerleri ise Brezilya için BCI ve GOLD serilerinde, Türkiye için ise BCI serisinde hem sabitli hem de sabitli ve trendli modelde durağanlığın olmadığına işaret ederken, diğer 
Sökmen, F.Ş. \& S. Yaman \& M.B. Tunçel (2021), "Piyasa Güven Endeksi ile Finansal Yatırım Araçları Arasındaki İlişki: BRICS ve MIST Ülkeleri Üzerine Bir Araştırma”, Sosyoekonomi, 29(50), 361-386.

serilerde tüm ülkelerde hem sabitli hem de sabitli ve trendli modellerde serilerin durağan olduklarına işaret etmektedir.

Tablo: 6

Pesaran (2007) CADF ve CIPS Birim Kök Testi

\begin{tabular}{|c|c|c|c|c|c|c|c|c|c|c|}
\hline \multirow{2}{*}{ Ülkeler } & \multicolumn{5}{|c|}{ Sabit Model } & \multicolumn{5}{|c|}{ Sabit ve Trendli Model } \\
\hline & BCI & INDEX & CUR & BOND & GOLD & BCI & INDEX & CUR & BOND & GOLD \\
\hline BRA & $-0,554$ & $-1,242$ & 1,095 & $-0,972$ & 1,919 & $-0,562$ & $-0,806$ & 0,604 & $-1,968$ & 0,558 \\
\hline RUS & $-2,364$ & $-2,106$ & $-3,235 *$ & $-2,575$ & $-0,223$ & $-3,241$ & $-2,076$ & $-3,256$ & $-2,600$ & $-2,593$ \\
\hline IND & $-2,892$ & $-2,361$ & $-2,115$ & $-0,878$ & $-1,210$ & $-2,820$ & $-2,653$ & $-2,730$ & $-2,481$ & $-2,047$ \\
\hline CHN & $-3,790 * *$ & $-2,743$ & $-1,783$ & $-2,295$ & $-2,269$ & $-4,751 * * *$ & $-2,774$ & $-1,424$ & $-2,947$ & $-2,880$ \\
\hline ZAF & $-0,396$ & $-1,140$ & $-2,130$ & $-1,316$ & 0,653 & $-1,078$ & $-2,009$ & $-2,142$ & $-2,220$ & $-1,144$ \\
\hline MEX & $-3,382 * *$ & $-1,585$ & $-1,491$ & $-1,951$ & 0,138 & $-2,880$ & $-1,128$ & $-1,522$ & $-2,586$ & $-2,573$ \\
\hline IDN & $-3,055^{*}$ & $-1,971$ & $-2,389$ & $-2,792$ & $-0,167$ & $-2,700$ & $-1,961$ & $-2,385$ & $-2,797$ & $-3,283$ \\
\hline KOR & $-2,428$ & $-2,863$ & $-2,518$ & $-1,675$ & $-0,415$ & $-2,525$ & $-2,855$ & $-2,508$ & $-2,013$ & $-3,272$ \\
\hline TUR & $-3,631 * *$ & $-2,763$ & $-0,163$ & $-0,537$ & $-3,262 * *$ & $-3,608^{*}$ & $-2,958$ & $-1,584$ & $-1,591$ & 0,583 \\
\hline CIPS & $-2,499 * *$ & $-2,086$ & $-1,636$ & $-1,666$ & 0,188 & $-2,685$ & $-2,136$ & $-1,883$ & $-2,356$ & $-1,850$ \\
\hline \multirow{2}{*}{ Ülkeler } & \multicolumn{5}{|c|}{ Sabit Model } & \multicolumn{5}{|c|}{ Sabit ve Trendli Model } \\
\hline & D(BCI) & D(INDEX) & D(CUR) & D(BOND) & D(GOLD) & D(BCI) & D(INDEX) & D(CUR) & D(BOND) & \begin{tabular}{|l} 
D(GOLD) \\
\end{tabular} \\
\hline BRA & $-2,049$ & $-7,353 * * *$ & $-3,747 * *$ & $-7,294 * * *$ & $-1,490$ & $-2,372$ & $-7,925 * * *$ & $-4,101 * *$ & $-7,327 * * *$ & $-1,904$ \\
\hline RUS & $-5,367 * * *$ & $-6,846 * * *$ & $-7,948 * * *$ & $-7,860 * * *$ & $-6,003^{* * *}$ & $-5,311 * * *$ & $-6,998 * * * *$ & $-7,877 * * *$ & $-7,937 * * *$ & $-6,007 * * *$ \\
\hline IND & $-3,510 * *$ & $-9,130 * * *$ & $-7,982 * * *$ & $-7,476^{* * * *}$ & $-7,789 * * *$ & $-3,477 *$ & $-9,122 * * *$ & $-7,955 * * *$ & $-7,572 * * *$ & $-7,754 * * *$ \\
\hline CHN & $-6,552 * * *$ & $-7,776 * * *$ & $-5,939 * * *$ & $-6,257 * * * *$ & $-9,147 * * *$ & $-6,619 * * *$ & $-7,755 * * *$ & $-6,210 * * *$ & $-6,259 * * *$ & $-9,112 * * *$ \\
\hline ZAF & $-4,410$ *** & $-6,305 * * *$ & $-5,312 * * *$ & $-7,902 * * *$ & $-4,085^{* * *}$ & $-4,843$ *** & $-6,523 * * *$ & $-5,339 * * *$ & $-7,948 * * *$ & $-4,172 * *$ \\
\hline MEX & $-3,627 * *$ & $-7,983 * * * *$ & $-6,331 * * *$ & $-7,407 * * *$ & $-5,599 * * *$ & $-3,641 *$ & $-8,442 * * *$ & $-6,401 * * *$ & $-7,396 * * *$ & $-5,706 * * *$ \\
\hline IDN & $-3,963 * * *$ & $-6,870$ **** & $-7,009^{* * *}$ & $-8,360 * * *$ & $-8,886^{* * * *}$ & $-4,015 * *$ & $-7,242 * * *$ & $-7,030 * * *$ & $-8,481^{* * * *}$ & $-8,873 * * *$ \\
\hline KOR & $-4,188 * * *$ & $-8,975 * * *$ & $-9,143^{* * *}$ & $-7,808 * * *$ & $-8,890^{* * * *}$ & $-4,259 * *$ & $-9,081 * * *$ & $-9,166^{* * * *}$ & $-7,836 * * *$ & $-8,877$ *** \\
\hline TUR & $-2,358$ & $-7,304 * * *$ & $-9,256^{* * *}$ & $-8,157$ **** & $-3,117 *$ & $-2,324$ & $-7,273 * * *$ & $-9,716^{* * * *}$ & $-8,166^{* * * *}$ & $-4,102 * *$ \\
\hline CIPS & $-4,003 * * *$ & $-7,616 * * *$ & $-6,959 * * *$ & $-7,613 * * *$ & $-6,112 * * *$ & $-4,096$ *** & $-7,818 * * *$ & $-7,088 * * *$ & $-7,658 * * *$ & $-6,279 * * *$ \\
\hline \multirow{4}{*}{ Kritik Değerler } & Düzey & \multicolumn{2}{|c|}{ CADF } & \multicolumn{2}{|c|}{ CIPS } & Düzey & \multicolumn{2}{|c|}{ CADF } & \multicolumn{2}{|c|}{ CIPS } \\
\hline & $\% 1$ & \multicolumn{2}{|c|}{$-3,88$} & \multicolumn{2}{|c|}{$-2,53$} & $\% 1$ & \multicolumn{2}{|c|}{$-4,35$} & \multicolumn{2}{|c|}{$-3,03$} \\
\hline & $\% 5$ & \multicolumn{2}{|c|}{$-3,24$} & \multicolumn{2}{|c|}{$-2,32$} & $\% 5$ & \multicolumn{2}{|c|}{$-3,72$} & \multicolumn{2}{|c|}{$-2,83$} \\
\hline & $\% 10$ & \multicolumn{2}{|c|}{$-2,92$} & \multicolumn{2}{|c|}{$-2,21$} & $\% 10$ & \multicolumn{2}{|c|}{$-3,41$} & \multicolumn{2}{|c|}{$-2,72$} \\
\hline
\end{tabular}

Tablo 7'de yer Hadri \& Kurozumi (2012) HK testi sonucunda, düzeyde BCI serisine ilişkin hem sabitli hem de sabitli ve trendli modellerde hem $Z_{A}^{S P C}$ hem de $Z_{A}^{L A}$ test istatistiklerinin serinin durağan olmadığını işaret ettiği, INDEX serisine ilişkin sabitli modelde hem $Z_{A}^{S P C}$ hem de $Z_{A}^{L A}$ test istatistiklerinin, sabitli ve trendli modelde ise $Z_{A}^{L A}$ test istatistiğinin serinin durağan olmadığını ișaret ettiği, CUR serisine ilișkin sabitli modelde $Z_{A}^{L A}$ test istatistiğinin, sabitli ve trendli modelde ise hem $Z_{A}^{S P C}$ hem de $Z_{A}^{L A}$ test istatistiklerinin serinin durağan olmadığını işaret ettiği, BOND serisine ilişkin sabitli modelde hem $Z_{A}^{S P C}$ hem de $Z_{A}^{L A}$ test istatistiklerinin, sabitli ve trendli modelde ise $Z_{A}^{L A}$ test istatistiğinin serinin durağan olmadığını işaret ettiği, GOLD serisine ilişkin sabitli modelde hem $Z_{A}^{S P C}$ hem de $Z_{A}^{L A}$ test istatistiklerinin serinin durağan olmadığına işaret ettiği tespit edilmiştir. Serilere ilişkin birinci fark sonuçları incelendiğinde; neredeyse tüm serilerde ve modellerde serilerin durağanlaştığı görülmektedir.

PANIC testi, CADF ve CIPS testleri ve HK testine ilişkin sonuçlar, genel anlamda birbirlerini desteklemekte ve veri setindeki serilerin düzeyde durağan olmadıkları ve birinci farklarında durağanlaştıklarını işaret etmektedirler. Bu durum seriler arasındaki uzun dönemli ilişkilerin eşbütünleşme analizleri ile incelenebilmesine imkân tanımaktadır. 
Tablo: 7

Hadri \& Kurozumi (2012) HK Birim Kök Testi

\begin{tabular}{|c|c|c|c|c|c|c|c|c|}
\hline \multirow{3}{*}{ Değiş̧kenler } & \multicolumn{4}{|c|}{ Sabit Model } & \multicolumn{4}{|c|}{ Sabit ve Trendli Model } \\
\hline & \multicolumn{2}{|c|}{$Z_{A}^{S P C}$} & \multicolumn{2}{|c|}{$Z_{A}^{L A}$} & \multicolumn{2}{|c|}{$Z_{A}^{S P C}$} & \multicolumn{2}{|c|}{$Z_{A}^{L A}$} \\
\hline & İstatistik & $\mathbf{p}$ & İstatistik & p & İstatistik & p & İstatistik & $\mathbf{p}$ \\
\hline BCI & 37,8875 & $0,001 * * *$ & 263,4820 & $0,001 * * *$ & 47,8235 & $0,001 * * *$ & 563,4767 & $0,001 * * *$ \\
\hline INDEX & 2,0646 & $0,0195 * *$ & 7,7295 & $0,001^{* * * *}$ & 1,6369 & 0,508 & 6,5182 & 0,001 *** \\
\hline CUR & 0,3485 & 0,3637 & 18,6039 & $0,001 * * *$ & 2,0539 & $0,0200 * *$ & 23,9510 & $0,001 * * *$ \\
\hline BOND & 13,3639 & $0,001 * * *$ & 5,1418 & 0,001 **** & 1,8419 & $0,0327 * *$ & 1,9829 & 0,237 \\
\hline GOLD & 57,3023 & $0,001 * * *$ & 65,9065 & 0,001 *** & 0,1639 & 0,4349 & 0,8975 & 0,1847 \\
\hline \multirow{3}{*}{ Değiş̧kenler } & \multicolumn{4}{|c|}{ Sabit Model } & \multicolumn{4}{|c|}{ Sabit ve Trendli Model } \\
\hline & \multicolumn{2}{|c|}{$Z_{A}^{S P C}$} & \multicolumn{2}{|c|}{$Z_{A}^{L A}$} & \multicolumn{2}{|c|}{$Z_{A}^{S P C}$} & \multicolumn{2}{|c|}{$Z_{A}^{L A}$} \\
\hline & İstatistik & $\mathbf{p}$ & İstatistik & $\mathbf{p}$ & İstatistik & $\mathbf{p}$ & İstatistik & Olasılık \\
\hline D(BCI) & $-0,9282$ & 0,8234 & 1,7376 & $0,0411 * *$ & 0,3740 & 0,3542 & 3,1697 & $0,001^{* * *}$ \\
\hline D(INDEX) & 2,3658 & $0,0090 * * *$ & 2,3078 & $0,0105 * *$ & $-1,5184$ & 0,9355 & $-1,5445$ & 0,9388 \\
\hline D(CUR) & 0,2256 & 0,4108 & 0,0319 & 0,4873 & $-0,7975$ & 0,7874 & $-0,9170$ & 0,8204 \\
\hline D(BOND) & $-0,6749$ & 0,7501 & $-0,6975$ & 0,7573 & $-1,2443$ & 0,8933 & $-1,2592$ & 0,8960 \\
\hline D(GOLD) & 0,5226 & 0,3006 & 0,5667 & 0,2855 & 0,5332 & 0,2970 & 0,4933 & 0,3109 \\
\hline \multicolumn{9}{|c|}{$\mathbf{H}_{0}$ : Seri durağandır } \\
\hline
\end{tabular}

\subsection{Panel Eșbütünleșme Analizi}

Düzeyde durağan olmayan seriler arasındaki ilişkiler incelenirken sahte regresyon problemi ile karşılaşılmaması için serilerin birinci farkları alınarak modelleme gerçekleştirilmektedir. Fakat bu durum seriler arasındaki uzun dönemli ilişkilerin incelenmesi için önemli olan bazı bilgilerin kaybedilmesine neden olmaktadır. Bu nedenle düzeyde durağan olmayan ve aynı dereceden birim kök içeren seriler arasındaki uzun dönemli ilişkiler eşbütünleşme analizleri ile incelenebilmektedir (Demir \& Görür, 2020:24). Çalışmada yatırımcı beklentileri ile finansal yatııı araçları serileri arasındaki uzun dönemli eşbütünleşme ilişskisi Westerlund (2007) Panel ECM ve Westerlund \& Edgerton (2007) Panel LM testleri ile incelenmiştir.

Westerlund (2007) hata düzeltme modeli temelli dört panel eşbütünleşme testi $\left(G_{\tau}\right.$, $\left.G_{\alpha}, P_{\tau}, P_{\alpha}\right)$ önermektedir. Her dört test de her birimin kendi hata düzeltmesine sahip olup olmadığına karar verilmesi yoluyla eşbütünleşmenin varlığı sınanma temeline dayanmaktadır. $G_{\tau}$ ve $G_{\alpha}$ istatistikleri birim bazında eşbütünleşmenin varlığını sınarken, $P_{\tau}$ ve $P_{\alpha}$ panel bazında eşbütünleşmenin varlığını sınamaktadır. Westerlund (2007) denklem (13)'te yer alan regresyon modelinden yola çıkarak denklem (14) ve (15)'te yer alan grup istatistiklerinin ve denklem (16) ve (17)'de yer alan panel istatistiklerinin hesaplanabileceğini ifade etmektedir (Westerlund, 2007: 715-718).

$$
\Delta y_{i t}=\delta_{i}^{\prime} d_{t}+\alpha_{i} y_{i t-1}+\lambda_{i}^{\prime} \chi_{i t-1}+\sum_{j=0}^{p_{i}} \gamma_{i j} \Delta \chi_{i t-j}+e_{i t}
$$

Denklem (13)'te yer alan $d_{t}=(1, t)^{\prime}$ deterministik bişleşenleri, $\delta_{i}^{\prime}=\left(\delta_{1 i}, \delta_{2 i}\right)^{\prime}$ parametrelerinin ilişki vektörünü, $\alpha_{i}$ hata düzeltme parametresini ifade etmektedir (Demir \& Görür, 2020: 25). Eğim katsayıları heterojen olan seriler arasındaki eşbütünleşme ilişkisinin incelenmesi için geliştirilen $G_{\tau}$ ve $G_{\alpha}$ istatistikleri, denklem (14) ve (15)'te verilmişken, 


$$
\begin{aligned}
G_{\tau} & =\frac{1}{N} \sum_{i=1}^{N} \frac{\widehat{\alpha}_{i}}{\operatorname{SE}\left(\widehat{\alpha}_{i}\right)} \\
G_{\alpha} & =\frac{1}{N} \sum_{i=1}^{N} \frac{T \widehat{\alpha}_{i}}{\widehat{\alpha}_{i}(1)}
\end{aligned}
$$

eğim katsayıları heterojen olan seriler arasındaki eşbütünleşme ilişkisinin incelenmesi için geliştirilen $P_{\tau}$ ve $P_{\alpha}$ istatistikleri, denklem (16) ve (17)'de verilmiştir.

$$
\begin{aligned}
& P_{\tau}=\frac{\widehat{\alpha}}{S E(\widehat{\alpha})} \\
& P_{\alpha}=T \hat{\alpha}
\end{aligned}
$$

Westerlund \& Edgerton (2007) Panel LM testi McCoskey \& Kao (1988) tarafindan geliştirmiş olan LM testine dayanmakta olup, bootstrap metodu sayesinde yatay kesit bağımlılığının olması durumunda panel bazında uzun dönemli eşbütünleşme ilişkisine dair tutarlı sonuçlar verebilmektedir (Westerlund \& Edgerton, 2007: 186-188). Panel LM test istatistiği denklem (18)'deki regresyon modelinden yola çıkılarak elde edilmektedir.

$$
y_{i t}=\alpha_{i}+\chi_{i t}^{\prime} \beta_{i t}+z_{i t}
$$

Denklem (18)'de $z_{i t}$ hata terimini ifade etmekte olup,

$$
z_{i t}=u_{i t}+v_{i t}, v_{i t}=\sum_{j=1}^{t} \eta_{i j}
$$

denklemi ile ifade edilmektedir. Burada $\eta_{i j}$ varyansı $\sigma_{i}^{2}$ olan ve ortalaması sıfir olan hata terimidir. Denklem (18)'den yola çıkarak Panel LM test istatistiği denklem (20) ile hesaplanmaktadir.

$$
L M_{N}^{+}=\frac{1}{N T^{2}} \sum_{i=1}^{N} \sum_{t=1}^{T} \omega_{i}^{-2} S_{i t}^{2}
$$

Denklem (20)'de $\omega_{i}^{-2} u_{i t}$ 'nin uzun dönem varyansını, $S_{i t}^{2}$ ise $z_{i t}$ hata teriminin kısmi toplamını ifade etmektedir.

Çalışma kapsamında kullanılan eşbütünleşme testlerinden Westerlund (2007) Panel ECM testi seriler arasında uzun dönemli eşbütünleşme ilişkisinin olmadığını ifade eden temel hipotezi sınarken, Westerlund \& Edgerton (2007) Panel LM testi ise seriler arasında uzun dönemli eşbütünleşme ilişkisinin var olduğunu ifade eden temel hipotezi sınamaktadır. Westerlund (2007) Panel ECM eşbütünleşme testi sonuçları Tablo 8'de, Westerlund \& Edgerton Panel LM Bootstrap eşbütünleşme testi sonuçları ise Tablo 9'da yer almaktadır.

Tablo 8'de yer alan Panel ECM eşbütünleşme analizi sonuçları değerlendirilirken modellerin homojen/heterojen yapıları dikkate alınmaktadır. Bu bağlamda $\tilde{\Delta}$ ve $\tilde{\Delta}_{a d j}$ testleri sonucunda heterojen yapıya sahip olduğu tespit edilen Model 2 ve Model 4 için $G_{\tau}$ ve $G_{\alpha}$ istatistikleri, homojen yapıya sahip olduğu tespit edilen Model 1 ve Model 3 için ise $P_{\tau}$ ve $P_{\alpha}$ istatistikleri dikkate alınmıştır. Panel ECM eşbütünleşme analizi sonucunda, Model 1 ve 
Model 3'e ilişkin $P_{\tau}$ ve $P_{\alpha}$ olasılık değerlerinin ve Model 2'ye ilişkin $G_{\tau}$ ve $G_{\alpha}$ olasılık değerlerinin hem sabit modelde hem de sabit ve trendli modellerde $\% 1$ anlamlılık düzeyinde ( $\mathrm{p}<0.01)$ anlamlı olduğu tespit edilmiş ve Model 1, Model 2 ve Model 3 için seriler arasında uzun dönem eşbütünleşme ilişkisinin olmadığını ifade eden $\mathrm{H}_{0}$ hipotezi reddedilmiştir. Model 4'e ilişskin sonuçlar incelendiğinde ise sabit modelde hem $G_{\tau}$ hem de $G_{\alpha}$ olasılık değerlerinin $\% 1$ anlamlılık düzeyinde $(\mathrm{p}<0.01)$ anlamlı olduğu, sabit ve trendli modelde $G_{\tau}$ olasılık değerinin $\% 5(\mathrm{p}<0.05)$ anlamlılık düzeyinde, $G_{\alpha}$ olasılık değerinin ise $\% 10$ anlamlılık düzeyinde ( $<<0.10)$ anlamlı olduğu ve seriler arasında uzun dönem eşbütünleşme ilişkisinin olduğu tespit edilmiştir. Panel ECM eşbütünleşme analizi sonuçlarına göre, BRICS ve MIST ülkelerinde yatırımcı beklentisi ile borsa endeksi getirisi, döviz kuru getirisi ve tahvil faizi getirisi arasında güçlü bir eşbütünleşme ilişkisinin olduğu tespit edilirken, yatırımcı beklentisi ile altın getirileri arasındaki eşbütünleşme ilişkisinin nispeten daha güçsüz kaldığı söylenebilir.

Tablo: 8

Westerlund (2007) Panel ECM Eşbütünleşme Testi

\begin{tabular}{|c|c|c|c|c|c|c|c|c|}
\hline \multirow{3}{*}{ Model } & \multicolumn{4}{|c|}{ Sabit Model } & \multicolumn{4}{|c|}{ Sabit ve Trendli Model } \\
\hline & \multicolumn{2}{|c|}{$G_{\tau}$} & \multicolumn{2}{|c|}{$G_{\alpha}$} & \multicolumn{2}{|c|}{$G_{\tau}$} & \multicolumn{2}{|c|}{$G_{\alpha}$} \\
\hline & İstatistik & $\mathbf{p}$ & İstatistik & $\mathbf{p}$ & İstatistik & $\mathbf{p}$ & İstatistik & $\mathbf{p}$ \\
\hline Model 2 & $-6,305$ & $0,001 * * *$ & $-40,719$ & $0,001 * * *$ & $-5,556$ & $0,001 * * *$ & $-32,462$ & $0,001 * * *$ \\
\hline Model 4 & $-5,749$ & $0,002 * * *$ & $-41,631$ & $0,005^{* * * *}$ & $-4,542$ & $0,014 * *$ & $-31,850$ & $0,092 *$ \\
\hline \multirow{3}{*}{ Model } & \multicolumn{4}{|c|}{ Sabit Model } & \multicolumn{4}{|c|}{ Sabit ve Trendli Model } \\
\hline & \multicolumn{2}{|c|}{$\boldsymbol{P}_{\tau}$} & \multicolumn{2}{|c|}{$\boldsymbol{P}_{\alpha}$} & \multicolumn{2}{|c|}{$\boldsymbol{P}_{\tau}$} & \multicolumn{2}{|c|}{$P_{\alpha}$} \\
\hline & İstatistik & $\mathbf{p}$ & Ístatistik & $\mathbf{p}$ & İstatistik & $\mathbf{p}$ & Ístatistik & $\mathbf{p}$ \\
\hline Model 1 & $-7,848$ & $0,001^{* * * *}$ & $-7,848$ & $0,001 * * *$ & $-7,313$ & $0,001 * * *$ & $-7,313$ & $0,001 * * *$ \\
\hline Model 3 & $-6,054$ & $0,001 * * *$ & $-6,054$ & $0,001 * * *$ & $-4,684$ & $0,001 * * *$ & $-4,684$ & $0,005^{* * * *}$ \\
\hline
\end{tabular}

Tablo 9'da yer alan Panle LM Bootstrap testi sonucunda, Model 1, Model 2 ve Model 3'e ilişkin olasılık değerlerinin hem sabit hem de sabit ve trendli modellerde $\% 10$ anlamlılık düzeyinde $(\mathrm{p}>0.10)$ anlamsız olduğu tespit edilmiş ve ilgili seriler arasında uzun dönem eşbütünleşme ilişkisinin olduğunu ifade eden $\mathrm{H}_{0}$ hipotezi reddedilememiştir. Model 4'e ilişkin olasılık değerlerinin ise sabit modelde \%10 anlamlılık düzeyinde $(p<0.10)$ ve sabit ve trendli modelde $\% 1$ anlamlılık düzeyinde $(\mathrm{p}<0.01)$ anlamlı olduğu tespit edilmiş ve seriler arasında uzun dönem eşbütünleşme ilişkisi olduğunu ifade eden $\mathrm{H}_{0}$ hipotezi reddedilmiştir.

Tablo: 9

Westerlund \& Edgerton (2007) Panel LM Bootstrap Eşbütünleşme Testi

\begin{tabular}{|c|c|c|c|c|}
\hline & \multicolumn{2}{|c|}{ Sabit } & \multicolumn{2}{|c|}{ Sabit ve Trendli } \\
\hline & İstatistik & $\mathbf{p}$ & İstatistik & $\mathbf{p}$ \\
\hline Model 1 & 0,367 & 0,198 & $-2,266$ & 0,840 \\
\hline Model 2 & 0,577 & 0,226 & 0,295 & 0,100 \\
\hline Model 3 & 0,212 & 0,407 & 0,742 & 0,119 \\
\hline Model 4 & 0,620 & $0,065 *$ & 5,166 & $0,001 * * *$ \\
\hline
\end{tabular}

Panel ECM ve Panel LM Bootstrap analizlerine ilişkin sonuçlarının genel anlamda birbirlerini desteklediği ve her iki analiz sonucunda da BRICS ve MIST ülkelerinde 
yatırımcı beklentisi ile borsa endeksi getirisi, döviz kuru getirisi ve tahvil faizi getirisi arasında eşbütünleşme ilişkisinin varlığına dair önemli istatistiki kanıtlar elde edildiği söylenebilir. Analizler sonucunda yatırımcı beklentisi ile altın getirileri arasındaki eşbütünleşme ilişkisinin varlığına dair kanıtların ise yetersiz kaldığını söylemek mümkündür.

\subsection{Panel Asimetrik Nedensellik Analizi}

Çalışmada piyasa güven endeksinde (yatırımcı beklentilerinde) meydana gelen değişimlerin borsa endeks getirileri, döviz kuru getirileri, devlet tahvili faiz getirileri ve ons altın getirilerindeki değişimlerin nedeni olup olmadığg ve bu getirilerdeki değişimlerin piyasa güven endeksindeki değişsimlerin nedeni olup olmadığı Hatemi (2011) panel asimetrik nedensellik testi ile incelenmiştir. Hatemi (2011) panel asimetrik nedensellik testi geleneksel nedensellik terslerinden farklı olarak seriler arasındaki pozitif şoklardan pozitif şoklara, pozitif şoklardan negatif şoklara, negatif şoklardan pozitif şoklara ve negatif şoklardan negatif şoklara olan nedenselliği incelemeye imkân tanımaktadır.

Hatemi (2011) panel asimetrik nedensellik testi, Granger \& Yoon (2002)'un öne sürdüğü asimetrik nedensellik analizinin geliştirilmiş bir versiyonu olup, pozitif ve negatif şokların etkileşimlerini ortaya çıkarmaktadır (Zortuk \& Yıldız, 2018: 133). Serilerin bütünleşik olduğu varsayıldığında denklem (21) ve (22)'deki gibi ifade edilebilir (Hatemi, 2011: 4).

$$
\begin{aligned}
& x_{i 1, t}=x_{i 1, t-1}+e_{i 1, t}=x_{i 1,0}+\sum_{j=1}^{t} e_{i 1, j} \\
& x_{i 2, t}=x_{i 2, t-1}+e_{i 2, t}=x_{i 2,0}+\sum_{j=1}^{t} e_{i 2, j}
\end{aligned}
$$

Denklem (21) ve (22)'de $i$ birimleri, $e_{i}$ ise beyaz gürültü hata terimini ifade etmektedir. Pozitif ve negatif şoklar ise sırasıyla denklem (23) ve denklem (24)'teki gibi gösterilebilir.

$$
\begin{aligned}
& e_{i 1, t}^{+}=\max \left(e_{i 1, t}, 0\right), e_{i 2, t}^{+}=\max \left(e_{i 2, t}, 0\right) \\
& e_{i 1, t}^{-}=\min \left(e_{i 1, t}, 0\right), e_{i 2, t}^{-}=\min \left(e_{i 2, t}, 0\right)
\end{aligned}
$$

Denklem (21), (22), (23) ve (24) doğrultusunda her bir serinin birikimli pozitif ve negatif şokları denklem (25), (26), (27) ve (28)'deki gibi ifade edilebilir.

$$
\begin{aligned}
& x_{i 1, t}^{+}=x_{i 1,0}^{+}+e_{i 1, t}^{+}=x_{i 1,0}+\sum_{j=1}^{t} e_{i 1, j}^{+} \\
& x_{i 2, t}^{+}=x_{i 2,0}^{+}+e_{i 2, t}^{+}=x_{i 2,0}+\sum_{j=1}^{t} e_{i 2, j}^{+} \\
& x_{i 1, t}^{-}=x_{i 1,0}^{-}+e_{i 1, t}^{-}=x_{i 1,0}+\sum_{j=1}^{t} e_{i 1, j}^{-} \\
& x_{i 2, t}^{-}=x_{i 2,0}^{-}+e_{i 2, t}^{-}=x_{i 2,0}+\sum_{j=1}^{t} e_{i 2, j}^{-}
\end{aligned}
$$


Serilere ilişkin pozitif ve negatif şoklar elde edildikten sonra şoklar arasındaki nedensellik ilişkisi $k$ gecikmeli VAR-SUR (vektor autoregressive seemingly unrelated regression) modeli kullanılarak test edilmektedir. İki seri arasında pozitif şoklardan pozitif şoklara $\left(x_{i 1, t}^{+}, x_{i 2, t}^{+}\right)$olan nedensellik, $k$ gecikmeli bir VAR-SUR modeli için denklem (29)'daki gibi hesaplanmaktadır (Hatemi, 2011: 5).

$$
\left[\begin{array}{c}
x_{i 1, t}^{+} \\
x_{i 2, t}^{+}
\end{array}\right]=\left[\begin{array}{c}
\beta_{i 0} \\
\gamma_{i 0}
\end{array}\right]+\left[\begin{array}{ll}
\sum_{r=1}^{k} \beta_{i 1, r} & \sum_{r=1}^{k} \beta_{i 2, r} \\
\sum_{r=1}^{k} \gamma_{i 1, r} & \sum_{r=1}^{k} \gamma_{i 2, r}
\end{array}\right] \times\left[\begin{array}{c}
x_{i 1, t-r}^{+} \\
x_{i 2, t-r}^{+}
\end{array}\right]+\left[\begin{array}{c}
\varepsilon_{i 1}^{+} \\
\varepsilon_{i 2}^{+}
\end{array}\right]
$$

Denklem (29) sonucunda elde edilen Wald test istatistiği üzerinden " $x_{2}$ ' deki pozitif şoklar $x_{l}$ 'deki pozitif şokların Granger nedeni değildir" şeklindeki temel hipotez test edilmektedir. Denklem (29) benzer şekilde pozitif şoklardan negatif şoklara $\left(x_{i 1, t}^{-}, x_{i 2, t}^{+}\right)$, negatif şoklardan negatif şoklara $\left(x_{i 1, t}^{-}, x_{i 2, t}^{-}\right)$ve negatif şoklardan pozitif şoklara $\left(x_{i 1, t}^{+}, x_{i 2, t}^{-}\right)$ olan nedensellik ilişkilerini ortaya koyacak şekilde düzenlenebilir (Hatemi, 2011: 5). Hatemi (2011) asimetrik nedensellik testi, bir serideki pozitif veya negatif şokların diğer serideki pozitif veya negatif şokların nedeni olmadığını ifade eden temel hipotezi sınamaktadır. Hatemi (2011) asimetrik nedensellik testine ilişkin panel bazında sonuçlar Tablo 10'da birim (ülke) bazında sonuçlar ise Ek 1, Ek 2, Ek 3 ve Ek 4 'te yer almaktadır. Panel ve ülke bazında tespit edilen asimetrik nedenselliğin yönleri ise Tablo 11'de özetlenmiştir.

Tablo: 10

\section{Hatemi (2011) Panel Asimetrik Nedensellik Sonuçları}

\begin{tabular}{|c|c|c|c|c|}
\hline & $\mathrm{BCI}^{+} \rightarrow \mathrm{INDEX}^{+}$ & $\mathrm{BCI}^{+} \rightarrow \mathrm{INDEX}^{-}$ & $\mathrm{BCI}^{-} \rightarrow \mathrm{INDEX}^{-}$ & BCI $^{-} \rightarrow$ INDEX $^{+}$ \\
\hline İstatistik & 36,440 & 22,831 & 44,113 & 38,669 \\
\hline \multirow[t]{2}{*}{ Olasılık } & $0,006 * * *$ & 0,197 & $0,001 * * *$ & $0,003 * * *$ \\
\hline & $\mathrm{INDEX}^{+} \rightarrow \mathrm{BCI}^{+}$ & INDEX $^{+} \rightarrow$ BCI $^{-}$ & INDEX $^{-} \rightarrow$ BCI $^{-}$ & INDEX $^{-} \rightarrow$ BCI $^{+}$ \\
\hline İstatistik & 36,650 & 36,306 & 17,815 & 19,804 \\
\hline \multirow[t]{2}{*}{ Olasılık } & $0,006^{* * *}$ & $0,006^{* * *}$ & 0,468 & 0,344 \\
\hline & $\mathrm{BCI}^{+} \rightarrow \mathrm{CUR}^{+}$ & $\mathrm{BCI}^{+} \rightarrow \mathrm{CUR}^{-}$ & $\mathrm{BCI}^{-} \rightarrow \mathrm{CUR}^{-}$ & $\mathrm{BCI}^{-} \rightarrow \mathrm{CUR}^{+}$ \\
\hline İstatistik & 24,397 & 13,908 & 15,935 & 33,137 \\
\hline \multirow[t]{2}{*}{ Olasılık } & 0,142 & 0,735 & 0,597 & $0,016 * *$ \\
\hline & $\mathrm{CUR}^{+} \rightarrow \mathrm{BCI}^{+}$ & $\mathrm{CUR}^{+} \rightarrow \mathrm{BCI}^{-}$ & $\mathrm{CUR}^{-} \rightarrow \mathrm{BCI}^{-}$ & $\mathrm{CUR}^{-} \rightarrow \mathrm{BCI}^{+}$ \\
\hline İstatistik & 79,449 & 46,629 & 26,889 & 24,655 \\
\hline \multirow[t]{2}{*}{ Olasılık } & $0,000 * * *$ & $0,000^{* * * *}$ & $0,081 *$ & 0,135 \\
\hline & $\mathrm{BCI}^{+} \rightarrow \mathrm{BOND}^{+}$ & $\mathrm{BCI}^{+} \rightarrow$ BOND $^{-}$ & $\mathrm{BCI}^{-} \rightarrow \mathrm{BOND}^{-}$ & $\mathrm{BCI}^{-} \rightarrow \mathrm{BOND}^{+}$ \\
\hline İstatistik & 20,016 & 29,746 & 15,080 & 33,223 \\
\hline \multirow[t]{2}{*}{ Olasılık } & 0,332 & $0,040 * *$ & 0,656 & $0,016 * *$ \\
\hline & BOND $^{+} \rightarrow$ BCI $^{+}$ & $\mathrm{BOND}^{+} \rightarrow \mathrm{BCI}^{-}$ & BOND $^{-} \rightarrow$ BCI $^{-}$ & BOND $^{-} \rightarrow$ BCI $^{+}$ \\
\hline Ístatistik & 22,286 & 33,162 & 27,907 & 19,085 \\
\hline \multirow[t]{2}{*}{ Olasılık } & 0,220 & $0,016^{* *}$ & $0,063 *$ & 0,387 \\
\hline & $\mathrm{BCI}^{+} \rightarrow \mathrm{GOLD}^{+}$ & $\mathrm{BCI}^{+} \rightarrow$ GOLD $^{-}$ & BCI $^{-} \rightarrow$ GOLD $^{-}$ & $\mathrm{BCI}^{-} \rightarrow \mathrm{GOLD}^{+}$ \\
\hline İstatistik & 31,568 & 38,385 & 21,386 & 56,655 \\
\hline \multirow[t]{2}{*}{ Olasılık } & $0,025^{* * *}$ & $0,003 * * *$ & 0,260 & $0,000 * * *$ \\
\hline & $\mathrm{GOLD}^{+} \rightarrow \mathrm{BCI}^{+}$ & GOLD $^{+} \rightarrow$ BCI $^{-}$ & GOLD $^{-} \rightarrow$ BCI $^{-}$ & GOLD $^{-} \rightarrow$ BCI $^{+}$ \\
\hline İstatistik & 31,233 & 21,998 & 31,765 & 20,915 \\
\hline Olasilık & $0,027 * *$ & 0,232 & $0,023 * *$ & 0,284 \\
\hline \multirow{4}{*}{ Hipotezler } & $\mathbf{X}^{+} \rightarrow \mathbf{Y}^{+}$ & \multicolumn{3}{|c|}{$\mathbf{H}_{0}$ : X'deki pozitif şoklar Y'deki pozitif şokların nedeni değildir } \\
\hline & $\mathbf{X}^{+} \rightarrow \mathbf{Y}^{-}$ & \multicolumn{3}{|c|}{$\mathbf{H}_{0}$ : X'deki pozitif şoklar Y'deki negatif şokların nedeni değildir } \\
\hline & $\mathbf{X}^{-} \rightarrow \mathbf{Y}^{*}$ & \multicolumn{3}{|c|}{$\mathbf{H}_{0}$ : X'deki negatif şoklar Y'deki negatif şokların nedeni değildir } \\
\hline & $\mathbf{X}^{-} \rightarrow \mathbf{Y}^{+}$ & \multicolumn{3}{|c|}{$\mathbf{H}_{0}$ : X'deki negatif şoklar Y'deki pozitif şokların nedeni değildir } \\
\hline
\end{tabular}


Sökmen, F.Ş. \& S. Yaman \& M.B. Tunçel (2021), "Piyasa Güven Endeksi ile Finansal Yatırım Araçları Arasındaki İlişki: BRICS ve MIST Ülkeleri Üzerine Bir Araştırma”, Sosyoekonomi, 29(50), 361-386.

BRICS ve MIST ülkelerinde yatırımcı beklentisi ile yatırım araçları arasında panel bazında asimetrik nedensellik ilişkisine dair elde edilen bazı önemli bulgular aşağıdaki gibi özetlenebilir.

- BCI ve INDEX serileri için incelendiğinde, panel bazında BCI ile INDEX arasında pozitif şoklardan pozitif şoklara karşılıklı bir nedensellik ilişkisinin bulunduğu ve BCI'deki negatif şokların INDEX'teki negatif şokların nedeni olduğu tespit edilmiştir. Bu sonuçlar, yatırımcıların ekonomiye ilişkin kısa dönemdeki pozitif beklentilerindeki artışın pay piyasalarında olumlu bir hava yarattığı ve pay getirilerinde artışa neden olduğunu, negatif beklentilerdeki artışın ise pay getirilerinde düşüşe neden olduğunu, benzer şekilde pay piyasalarındaki yükselişlerin de yatırımcıların ekonomiye ilişkin kısa dönemli beklentilerini pozitif yönde etkilediği anlamına gelmektedir.

- BCI ve CUR serileri arasındaki asimetrik nedensellik ilişkisine yönelik sonuçlar incelendiğinde, panel bazında CUR'daki pozitif şokların BCI'deki negatif şokların nedeni olduğu, BCI'daki negatif şokların ise CUR'daki pozitif şokların nedeni olduğu tespit edilmiştir. Bu sonuçlar, döviz kurundaki yükselişlerin yatırımcıların ekonomiye dair kısa dönemli beklentilerinde negatif bir etki yarattığı ve söz konusu olumsuz beklentilerin döviz kurundaki artışın devam edeceğine dair beklentileri artırdığ 1 ve yatırımcıların döviz yatırımlarına yöneldiği ve dolayısıyla oluşan talep nedeniyle döviz kurunda yükselişe neden olduğunu işaret etmektedir.

- BCI ile BOND serileri arasındaki asimetrik nedensellik ilişkisine yönelik sonuçlar incelendiğinde, panel bazında BCI ve BOND arasında pozitif şoklardan negatif şoklara karşılıklı bir nedensellik ilişkisinin bulunduğu ve BCI'deki negatif şokların BOND'daki pozitif şokların nedeni olduğu tespit edilmiştir. Bu sonuçlar, yatırımcıların ekonomiye dair beklentilerindeki pozitif/negatif değişimlerin devlet tahvili gibi teorik olarak risksiz olduğu kabul edilen bir yatırım aracına ilişkin getirilerde negatif/pozitif bir etki yarattığı şeklinde yorumlanabilir. Diğer bir ifadeyle, ekonomiye ilişkin olumlu beklentilere sahip olan yatırımcılar risksiz bir yatırım aracına yatırım yaparak düşük getiriyi kabul etmek yerine riskli yatırım araçlarına yatırım yaparak yüksek getiri elde etmeyi hedeflemektedirler. Ekonomiye ilişkin olumsuz beklentilerin yükseldiği dönemlerde ise yatırımcılar riskten kaçınmak adına tahvil yatırımlarına ağırlık vermekte ve bu durum oluşan talep nedeniyle tahvil faizlerinde yükselişe neden olmaktadır.

- BCI ile GOLD serileri arasındaki asimetrik nedensellik ilişkisine yönelik sonuçlar incelendiğinde, panel bazında BCI'daki pozitif şokların GOLD'daki negatif şokların nedeni olduğu ve BCI'daki negatif şokların GOLD'daki pozitif şokların nedeni olduğu tespit edilmiştir. Bu sonuçlar, yatırımcıların ekonomiye dair beklentilerindeki pozitif/negatif değişimlerin yatırımcılar için güvenli liman olarak bilinen altına ilişkin getirilerde negatif/pozitif bir etki yarattığ yorumlanabilir. Diğer bir ifadeyle, ekonomiye ilişkin olumlu beklentilere sahip olan yatırımcılar düşük riskli bir yatırım aracı olarak düşünülebilecek olan altına yatırım yapmak yerine riskli yatırım araçlarına yönelmektedirler. Ekonomiye 
Sökmen, F.Ş. \& S. Yaman \& M.B. Tunçel (2021), "Piyasa Güven Endeksi ile Finansal Yatırım Araçları Arasındaki İlişki: BRICS ve MIST Ülkeleri Üzerine Bir Araştırma”, Sosyoekonomi, 29(50), 361-386.

ilişkin olumsuz beklentilerin yükseldiği dönemlerde ise yatırımcılar riskten kaçınmak adına yatırımlarını güvenli liman olarak ifade edilen altına yönlendirmekte ve bu durum oluşan talep nedeniyle altın fiyatlarında ve getirilerinde yükselişe neden olmaktadır.

Ülke bazında yatırımcı beklentisi ile yatırım araçları arasındaki asimetrik nedensellik ilişkisine dair elde edilen bazı önemli bulgular aşağıdaki gibi özetlenebilir.

- Ülke bazında asimetrik nedensellik analizleri sonucunda, Brezilya ve Endonezya'da yatırımcı güveni ve beklentisindeki pozitif şokların pay piyasasındaki pozitif şokların nedeni olduğu tespit edilirken, Rusya ve Hindistan'da ise pay piyasasındaki pozitif şokların yatırımcı güveni ve beklentisindeki pozitif şokların nedeni olduğu tespit edilmiştir. Rusya, Hindistan ve Güney Kore'de yatırımcı beklentisindeki negatif şokların pay piyasasındaki negatif şokların nedeni olduğu tespit edilirken, Brezilya' da yatırımcı beklentisi ve pay piyasası arasında negatif şoklardan negatif şoklara çift yönlü bir nedensellik ilişkisinin bulunduğu tespit edilmiştir. Benzer şekilde Meksika'da yatırımcı beklentisi ve pay piyasası arasında negatif şoklardan pozitif şoklara çift yönlü bir nedensellik ilişkisinin bulunduğu tespit edilmiştir. Endonezya'da ise pay piyasasındaki pozitif şokların yatırımcı beklentisindeki negatif şokların nedeni olduğu tespit edilmiştir. Türkiye'de pay piyasası ve yatırımcı güven ve beklentileri arasında herhangi bir asimetrik nedensellik ilişkisine rastlanmamıştır.

Tablo: 11

Panel ve Ülke Bazında Asimetrik Nedenselliğin Yönü

\begin{tabular}{|c|c|c|c|c|c|c|c|c|c|c|c|}
\hline Panel & $\mathbf{X}^{+} \rightarrow \mathbf{Y}^{+}$ & $\mathbf{X}^{+} \rightarrow \mathbf{Y}^{-}$ & $\mathbf{X}^{-} \rightarrow \mathbf{Y}^{-}$ & $\mathbf{X}^{-} \rightarrow \mathbf{Y}^{+}$ & & BRA & $\mathbf{X}^{+} \rightarrow \mathbf{Y}^{+}$ & $\mathbf{X}^{+} \rightarrow \mathbf{Y}^{-}$ & $\mathbf{X}^{-} \rightarrow \mathbf{Y}^{-}$ & $\mathbf{X}^{-} \rightarrow \mathbf{Y}^{+}$ & \\
\hline INDEX & $\leftrightarrow$ & $\rightarrow$ & $\leftarrow$ & $\leftarrow$ & BCI & \begin{tabular}{|l|} 
INDEX \\
\end{tabular} & $\leftarrow$ & $\leftrightarrow$ & $\leftrightarrow$ & $\leftarrow$ & BCI \\
\hline CUR & $\rightarrow$ & $\rightarrow$ & $\rightarrow$ & $\leftarrow$ & BCI & CUR & & $\rightarrow$ & & $\leftarrow$ & BCI \\
\hline BOND & & $\leftrightarrow$ & $\rightarrow$ & $\leftarrow$ & BCI & BOND & $\rightarrow$ & & & & BCI \\
\hline GOLD & $\leftrightarrow$ & $\leftarrow$ & $\rightarrow$ & $\leftarrow$ & BCI & GOLD & & & & $\leftarrow$ & BCI \\
\hline RUS & $\mathbf{X}^{+} \rightarrow \mathbf{Y}^{+}$ & $\mathbf{X}^{+} \rightarrow \mathbf{Y}^{-}$ & $\mathbf{X}^{*} \rightarrow \mathbf{Y}^{*}$ & $\mathbf{X}^{-} \rightarrow \mathbf{Y}^{+}$ & & IND & $\mathbf{X}^{+} \rightarrow \mathbf{Y}^{+}$ & $\mathbf{X}^{+} \rightarrow \mathbf{Y}^{-}$ & $\mathbf{X}^{-} \rightarrow \mathbf{Y}^{-}$ & $\mathbf{X}^{-} \rightarrow \mathbf{Y}^{+}$ & \\
\hline INDEX & $\rightarrow$ & $\leftarrow$ & $\leftarrow$ & & BCI & \begin{tabular}{|l|} 
INDEX \\
\end{tabular} & $\rightarrow$ & & $\leftarrow$ & $\leftarrow$ & BCI \\
\hline CUR & $\rightarrow$ & & & & BCI & CUR & $\rightarrow$ & $\rightarrow$ & $\rightarrow$ & $\leftarrow$ & BCI \\
\hline BOND & & & & & BCI & BOND & & $\leftrightarrow$ & $\rightarrow$ & & BCI \\
\hline GOLD & & & & & BCI & GOLD & & & & & BCI \\
\hline CHN & $\mathbf{X}^{+} \rightarrow \mathbf{Y}^{+}$ & $\mathbf{X}^{+} \rightarrow \mathbf{Y}^{-}$ & $\mathbf{X}^{-} \rightarrow \mathbf{Y}^{*}$ & $\mathbf{X}^{-} \rightarrow \mathbf{Y}^{+}$ & & ZAF & $\mathbf{X}^{+} \rightarrow \mathbf{Y}^{+}$ & $\mathbf{X}^{+} \rightarrow \mathbf{Y}^{-}$ & $\mathbf{X}^{-} \rightarrow \mathbf{Y}^{-}$ & $\mathbf{X}^{-} \rightarrow \mathbf{Y}^{+}$ & \\
\hline INDEX & & & & & BCI & INDEX & & & & & BCI \\
\hline CUR & $\leftrightarrow$ & & & $\rightarrow$ & BCI & CUR & $\rightarrow$ & & & & BCI \\
\hline BOND & & $\leftarrow$ & & $\rightarrow$ & BCI & BOND & & & & & BCI \\
\hline GOLD & $\leftarrow$ & $\leftarrow$ & $\leftrightarrow$ & & BCI & GOLD & $\leftrightarrow$ & & & $\leftarrow$ & BCI \\
\hline MEX & $\mathbf{X}^{+} \rightarrow \mathbf{Y}^{+}$ & $\mathbf{X}^{+} \rightarrow \mathbf{Y}^{*}$ & $\mathbf{X}^{-} \rightarrow \mathbf{Y}^{-}$ & $\mathbf{X}^{-} \rightarrow \mathbf{Y}^{+}$ & & IDN & $\mathbf{X}^{+} \rightarrow \mathbf{Y}^{+}$ & $\mathbf{X}^{+} \rightarrow \mathbf{Y}^{-}$ & $\mathbf{X}^{-} \rightarrow \mathbf{Y}^{-}$ & $\mathbf{X}^{-} \rightarrow \mathbf{Y}^{+}$ & \\
\hline INDEX & & & & $\leftrightarrow$ & BCI & INDEX & $\leftarrow$ & $\rightarrow$ & & & BCI \\
\hline CUR & $\leftarrow$ & & & $\leftarrow$ & BCI & CUR & $\leftarrow$ & $\rightarrow$ & & $\rightarrow$ & BCI \\
\hline BOND & & & & & BCI & BOND & $\leftarrow$ & $\rightarrow$ & $\leftarrow$ & $\leftarrow$ & BCI \\
\hline GOLD & & & & & BCI & GOLD & & $\leftarrow$ & & $\leftrightarrow$ & BCI \\
\hline KOR & $\mathbf{X}^{+} \rightarrow \mathbf{Y}^{+}$ & $\mathbf{X}^{+} \rightarrow \mathbf{Y}^{*}$ & $\mathbf{X}^{*} \rightarrow \mathbf{Y}^{-}$ & $\mathbf{X}^{-} \rightarrow \mathbf{Y}^{+}$ & & TUR & $\mathbf{X}^{+} \rightarrow \mathbf{Y}^{+}$ & $\mathbf{X}^{+} \rightarrow \mathbf{Y}^{-}$ & $\mathbf{X}^{-} \rightarrow \mathbf{Y}^{-}$ & $\mathbf{X}^{-} \rightarrow \mathbf{Y}^{+}$ & \\
\hline INDEX & & & $\leftarrow$ & & BCI & INDEX & & & & & BCI \\
\hline CUR & $\rightarrow$ & & & & BCI & CUR & & & & & BCI \\
\hline BOND & & & & & BCI & \begin{tabular}{|l|} 
BOND \\
\end{tabular} & & $\leftrightarrow$ & & & BCI \\
\hline GOLD & $\rightarrow$ & & $\leftarrow$ & $\leftrightarrow$ & BCI & GOLD & & & & $\leftarrow$ & BCI \\
\hline \multicolumn{12}{|c|}{$\begin{array}{l}\text { Not 1: X bağımsız değişkeni, Y ise bağımlı değişkeni ifade etmektedir. } \\
\text { Not 2: + işareti ilgili değişkendeki pozitif şokları, - işareti ilgili değişkendeki negatif şokları ifade etmektedir. } \\
\text { Not 3: } \rightarrow \text { işareti ilgili satırda bulunan değişkenden BCI değişkenine doğru olan nedensellik ilişkisini, } \leftarrow \text { işareti BCI değişkeninden ilgili satırda bulunan } \\
\text { değişkene doğru olan nedensellik ilişkisini, } \leftrightarrow \text { işareti ise BCI değişkeni ile ilgili satırda bulunan değişken arasındaki çift yönlü nedensellik ilişkisini } \\
\text { ifade etmektedir. }\end{array}$} \\
\hline
\end{tabular}


- Analizler sonucunda, Brezilya, Hindistan ve Endonezya'da döviz kurlarındaki pozitif şoklardan yatırımcı güveni ve beklentisindeki negatif şoklara doğru tek yönlü bir nedensellik ilişkisi tespit edilmiştir. Bu bulguları destekleyecek şekilde, Brezilya ve Hindistan'da yatırımcı beklentisindeki negatif şoklardan döviz kurundaki pozitif şoklara ve Endonezya'da döviz kurundaki negatif şoklardan yatırımcı beklentisindeki pozitif şoklara tek yönlü nedensellik ilişkilerinin olduğu tespit edilmiştir. Rusya, Çin, Güney Afrika ve Güney Kore'de ise döviz kurundaki pozitif şokların yatırımcı beklentisindeki pozitif şokların nedeni olduğu tespit edilmiştir. Söz konusu nedensellik ilişkisi Çin için çift yönlü olarak elde edilmiştir. Meksika'da ise yatırımcı beklentisindeki negatif şoklardan döviz kurundaki pozitif şoklara doğru tek yönlü bir nedensellik ilişkisi tespit edilmiştir. Türkiye'de döviz kuru ve yatırımc1 güven ve beklentileri arasında herhangi bir asimetrik nedensellik ilişkisine rastlanmamıştır.

- Tahvil faizleri ile yatırımci beklentileri arasındaki nedensellik analizleri sonucunda, Hindistan ve Türkiye'de yatırımcı beklentileri ile tahvil faizleri arasında pozitif şoklardan negatif şoklara doğru karşılıklı bir nedensellik ilişkisinin bulunduğu tespit edilmiştir. Çin'de yatırımcı beklentilerindeki pozitif şokların tahvil faizlerindeki negatif şokların nedeni olduğu, tahvil faizlerindeki negatif şokların ise yatırımcı beklentilerindeki pozitif şokların nedeni olduğu tespit edilmiştir. Benzer şekilde Endonezya'da tahvil faizlerindeki pozitif şokların yatırımcı beklentilerindeki negatif şokların nedeni olduğu ve yatırımcı beklentilerindeki negatif şokların tahvil faizlerindeki pozitif şokların nedeni olduğu tespit edilmiştir. Brezilya'da ise diğer ülkelerin aksine yatırımcı beklentilerindeki pozitif şoklardan tahvil faizlerindeki pozitif şoklara doğru bir nedensellik ilişkisi tespit edilmiştir. Rusya, Güney Afrika, Meksika ve Güney Kore'de ise tahvil faizleri ile yatırımcı güven ve beklentileri arasında herhangi bir asimetrik nedensellik ilişkisine rastlanmamıştır.

- Altın ile yatırımcı beklentileri arasındaki nedensellik analizleri sonucunda, Brezilya ve Türkiye'de yatırımcı beklentilerindeki negatif şoklardan altındaki pozitif şoklara doğru tek yönlü bir nedensellik ilişkisi tespit edilirken, söz konusu ilişki Endonezya'da çift yönlü olarak tespit edilmiştir. Ayrıca Endonezya'da yatırımcı beklentilerindeki pozitif şokların altındaki negatif şokların nedeni olduğu tespit edilmiştir. Çin'de yatırımcı beklentilerindeki pozitif şoklardan altındaki pozitif şoklara doğru ve Güney Kore'de altındaki pozitif şoklardan yatırımcı beklentilerindeki şoklara doğru tek yönlü bir nedensellik ilişkisi tespit edilirken, Güney Afrika'da bu ilişki çift yönlü olarak elde edilmiştir. Ayrıca, Güney Kore'de yatırımcı beklentilerindeki negatif şoklardan altındaki negatif şoklara doğru tek yönlü bir nedensellik ilişkisi tespit edilirken, Çin’de söz konusu ilişkinin çift yönlü olduğu tespit edilmiştir. Rusya, Hindistan ve Meksika'da ise altın ile yatırımcı güven ve beklentileri arasında herhangi bir asimetrik nedensellik ilişkisine rastlanmamıştır. 
Sökmen, F.Ş. \& S. Yaman \& M.B. Tunçel (2021), "Piyasa Güven Endeksi ile Finansal Yatırım Araçları Arasındaki İlişki: BRICS ve MIST Ülkeleri Üzerine Bir Araştırma”, Sosyoekonomi, 29(50), 361-386.

\section{Sonuç}

Yatırımcıların piyasaya ve iş dünyasına karşı güvenleri ve gelecekle ilgili beklentileri, finansal piyasalarda işlem gören yatırım araçlarının fiyat ve getirilerini yakından ilgilendirmektedir. Yatırımcıların ekonomiye dair güven ve beklenti düzeyleri, tasarrufların risk düzeyi farklı finansal yatırım araçlarına yatırım yapılarak değerlendirilmesi noktasındaki kararları üzerinde etkili olabilmektedir. Etkin piyasa hipotezi ve beklenen fayda teorisi, yatırımcıların yatırım kararları noktasında rasyonel hareket ettiğini ve yatırım politikalarının beklenen getiriyi maksimize edecek şekilde belirlendiğini ileri sürmektedir. Fakat ilgili konuda gerçekleştirilen birçok çalışma, piyasaların etkin olmadığ ve yatırımcıların piyasaya gelen bilgiler karşısında aşırı veya yetersiz tepki verdiklerini ortaya koymuştur. Davranışsal finans modelleri ile açıklanan ve yatırımcı psikolojisi ile ilişkilendirilen söz konusu rasyonel olmayan yatırımcı davranışları, kişiden kişiye değişebildiği gibi farklı ülkelerde de farklı şekilde karşımıza çıkabilmektedir.

Bu çalışmada yatırımcıların ekonomi ve iş dünyasına ilişkin güven ve beklentileri ile finansal yatırım araçları getirileri arasındaki uzun dönem eşbütünleşme ilişkisi ve asimetrik nedensellik ilişkisi incelenmiştir. Çalışmada yatırımcı güven ve beklentileri ile finansal yatırım araçları arasındaki ilişkilerin tahmininde kullanılacak yönteme karar vermek amacıyla; her bir seri ve model için yatay kesit bağımlılığı ve homojenite durumu ve her bir seri için durağanlık durumu çeşitli testler kullanılarak kontrol edilmiştir. Yatay kesit bağımlılığı ve homojenite test sonuçlarının serilere ve modellere göre farklılık gösterdiği tespit edilirken durağanlık testleri sonucunda tüm serilerin düzeyde birim kök içerdikleri ve birinci farklarında durağanlaştıkları tespit edilmiştir.

Eşbütünleşme analizleri sonucunda, BRICS ve MIST ülkelerinde yatırımcı beklentileri ile borsa endeksi getirisi, döviz kuru getirisi ve tahvil faizi getirisi arasında uzun dönem eşbütünleşme ilişkisinin varlığına dair önemli istatistiki bulgular elde edilirken yatırımcı beklentileri ile altın getirileri arasındaki uzun dönem eşbütünleşme ilişkisinin varlığına dair bulguların ise yetersiz kaldığı tespit edilmiştir. Yatırımcı beklentileri ile yatırım araçları arasında panel bazında gerçekleştirilen asimetrik nedensellik analizi sonucunda; BRICS ve MIST ülkelerinde ekonomiye ilişkin pozitif beklentilerdeki artışın pay piyasalarında olumlu bir hava yarattığ 1 ve pay getirilerinde artışa neden olduğu, negatif beklentilerdeki artışın ise pay getirilerinde düşüşe neden olduğu; döviz kurundaki yükselişlerin yatırımcı beklentilerinde negatif bir etki yarattığı, yatırımcıların döviz kurlarında yükseliş beklentisi ile döviz yatırımlarına yöneldiği ve dolayısıyla oluşan talep nedeniyle döviz kurunda yükselişe neden olduğu; yatırımcı beklentilerinin arttı̆̆ dönemlerde teorik olarak risksiz olduğu kabul edilen devlet tahvilinin faiz getirisinin azaldığı, yatırımcı beklentilerinin azaldığ 1 dönemlerde ise tahvil faiz getirilerinin arttığ1, diğer bir ifadeyle yatırımcıların sahip oldukları olumlu beklentiler nedeniyle risksiz bir yatırım aracına yatırım yapmak yerine riskli yatırım araçlarına yöneldiği ve yüksek getiri elde etmeyi hedeflediği; benzer şekilde yatırımcı beklentilerinin azaldığ 1 dönemlerde güvenli liman olarak bilinen altına ilişkin getirilerin azaldığı, yatırımcı beklentilerinin arttığ dönemlerde ise yatırımcıların altın yerine riskli yatırımlara yöneldiği ve bu durum karşısında 
altın getirilerinin azaldığına ilişkin önemli istatistiki bulgular elde edilmiştir. Ülke bazında elde edilen asimetrik nedensellik analizleri sonucunda, gerek finansal yatırım araçlarındaki değişimlerin yatırımcı beklentileri üzerine olan etkileri, gerekse yatırımcı beklentilerinin finansal yatırım araçları getirileri üzerine olan etkileri noktasında ülkeler arasında ciddi farklılıklar gözlemlenmiştir. Elde edilen bu sonuçlar, farklı ülkelerdeki yatırımcıların farklı risk algısı ve yatırım perspektifine sahip olmaları ve piyasaların etkin olmaması ile açıklanabilir. Ayrıca çalışma bulguları, risk algısının ülkelere göre farklılaşmasının ülkeler arasındaki ekonomik, kültürel, coğrafik ve demografik farklılıklardan da kaynaklanabileceğini işaret etmektedir. Çalışma sonucunda piyasa güven endeksi ve finansal yatırım araçları arasındaki ilişkilere ilişkin elde edilen bulgular genel anlamda Asgary \& Gu (2005), Bandopadhyaya \& Jones (2006), Korkmaz \& Çevik (2009), Hsu vd. (2011), Kale \& Akkaya (2016), Eyüboğlu \& Eyüboğlu (2017), Güngör (2019), Evci (2019) ve Barışık \& Dursun (2020) çalışmalarıyla benzerlik göstermektedir.

Çalışmada elde edilen bulguların yatırımcılar başta olmak üzere, yatırım danışmanlık firmaları, politika yapıcılar, araştırmacılar ve akademisyenler gibi farklı kesimlerden ilgililere yatırım analizleri ve yatırımcı beklentilerinin daha iyi anlaşılması noktasında fayda sağlayacağı düşünülmektedir. Gelecek çalışmalarda, ülkelerdeki ekonomik, kültürel, coğrafik ve demografik farklılıkların yatırımcı risk algısı üzerine olan etkilerinin araştırılması literatüre katkı sağlayacaktır.

\section{Kaynaklar}

Alhaj, A.A. \& A.M. Awn (2020), "Financial Instruments and Their Impact on the Growth of Investment-A Study on the Libyan Market", European Journal of Economic and Financial Research, 4(3), 158-173.

Asgary, N. \& A.Y. Gu (2005), “The Stock Market and Consumer Confidence: An International Comparison”, Journal of Accounting and Finance Research, 13(3), 205-213.

Bai, J. \& S. Ng (2004), “A PANIC Attack on Unit Roots and Cointegration”, Econometrica, 72(4), 1127-1177.

Bandopadhyaya, A. \& A.L. Jones (2006), "Measuring Investor Sentiment in Equity Market”, Journal of Asset Management, 7, 208-215.

Barışık, S. \& E. Dursun (2009), “Türkiye'de Ekonomik Güven Endeksi ile Altın Fiyatları ve Döviz Kuru Arasındaki İlişkinin Analizi”, Journal of Institute of Economic Development and Social Researches, 6(23), 370-384.

Beşiktaşl1, D.K. \& Ç.K. Cihangir (2020), “Tüketici Güven Endeksinin Finansal Piyasalara ve Makroekonomik Yapıya Etkisi”, Finans Ekonomi ve Sosyal Araştırmalar Dergisi, 5(1), 54-67.

Breusch, T.S. \& A.R. Pagan (1980), “The Lagrange Multiplier Test and Its Applications to Model Specification in Econometrics”, Review of Economic Studies, 47(1), 239-253.

Choi, I. (1993), “Asymptotic Normality of the Least-Squares Estimates for Higher Order Autoregressive Integrated Processes with Some Applications”, Econometric Theory, 9, 263-282. 
Sökmen, F.Ş. \& S. Yaman \& M.B. Tunçel (2021), "Piyasa Güven Endeksi ile Finansal Yatırım Araçları Arasındaki İlişki: BRICS ve MIST Ülkeleri Üzerine Bir Araştırma”, Sosyoekonomi, 29(50), 361-386.

Choi, I. (2001), "Unit Root Tests for Panel Data”, Journal of International Money and Finance, 20, 249-272.

Çil-Yavuz, N. (2015), Finansal Ekonometri, (2. Bask1), İstanbul: Der Yayınevi.

De Hoyos, E.R. \& V. Sarafidis (2006), "The Testing for Cross-Sectional Dependence in Panel Data Model", The Stata Journal, 6(4), 482-496.

Demir, Y. \& Ç. Görür (2020), “OECD Ülkelerine Ait Çeşitli Enerji Tüketimleri ve Ekonomik Büyüme Arasındaki İlişkinin Panel Eşbütünleşme Analizi ile İncelenmesi”, Journal of Econometrics and Statistics, 32, 15-33.

Evci, S. (2019), "Ekonomik Güven Endeksi ile Yatırım Araçları Arasındaki Nedensellik İlişkisi: Toda-Yamamoto Yaklaşımı", İsletme Araştırmaları Dergisi, 11(4), 2893-2901.

Eyüboğlu, K. \& S. Eyüboğlu (2017), "Ekonomik Güven Endeksi ile Hisse Senedi Fiyatları Arasındaki İlişkinin İncelenmesi: Türkiye Örneği”, Gazi Üniversitesi İktisadi ve İdari Bilimler Fakültesi Dergisi, 19(2), 603-614.

Ferreira, E.M. et al. (2007), "Economic Sentiment and Yield Spreads in Europe", European Financial Management, 14(2), 206-221.

Gujarati, D.N. (2004), Basic Econometrics, (4th Edition), New York: The McGraw-Hill Companies.

Güngör, S. (2019), "Ekonomik Güven Endeksi ve Finansal Yatırım Araçları Getirileri Arasındaki Nedensellik İlişkisi: 2007-2017 Döneminde ABD Doları ve Altın Getirileri Örneği”, Yönetim ve Ekonomi Araştırmaları Dergisi, 17(1), 22-39.

Hadri, K. \& E. Kurozumi (2012), “A Simple Panel Stationarity Test in the Presence of Serial Correlation and a Common Factor", Economic Letters, 115, 31-34.

Hatemi-J, A. (2011), "Asymmetric Panel Causality Tests with an Application to the Impact of Fiscal Policy on Economic Performance in Scandinavia", Working Paper, Munich Personal RePEc Archive-MPRA, Working Paper No: 55527.

Hsu, C.C. et al. (2011), "Consumer Confidence and Stock Markets: The Panel Causality Evidence”, International Journal of Economics and Finance, 3(6), 91-98.

Kale, S. \& M. Akkaya (2016), "The Relation Between Confidence Climate and Stock Returns: The Case of Turkey", Procedia Economics and Finance, 38, 150-162.

Kara, F.Z. vd. (2009), "Yatırımcı İlişkileri Yönetiminde Güven ve Ekonomiye Etkisi”, Afyon Kocatepe Üniversitesi İktisadi ve İdari Bilimler Fakültesi Dergisi, 11(1), 279-307.

Korkmaz, T. \& E.İ. Çevik (2009), "Reel Kesim Güven Endeksi ile İMKB 100 Endeksi Arasındaki Dinamik Nedensellik İlişkisi”, İstanbul Üniversitesi Isşletme Fakültesi Dergisi, 38(1), 24 37.

Los, V. \& D. Ocheretin (2019), "Prediction of Business Confidence Index Based on a System of Economic Indicators", in: Proceedings of the Selected Papers of the 8th International Conference on Monitoring, Modeling \& Management of Emergent Economy, Odessa, Ukraine, 237-248.

Madalla, G.S. \& S. Wu (1999), “A Comparative Study of Unit Root Tests with Panel Data and a New Simple Test”, Oxford Bulletin of Economics and Statistics, Special Issue, 631-652.

McCoskey, S. \& C. Kao (1998), "A Residual-Based Test of the Null of Cointegration in Panel Data", Econometric Reviews, 17, 57-84. 
Menyah, K. et al. (2014), "Financial Development, Trade Openness and Economic Growth in African Countries: New Insights From a Panel Causality Approach”, Economic Modeling, 37, 386-394.

OECD (N/A), Business Confidence Index, <https://data.oecd.org/leadind/business-confidence-indexbci.htm>, 05.02.2021.

Oral, E. et al. (2005), "Building up a Real Sector Business Confidence Index for Turkey", Central Bank Review, 5(1), 23-54.

Ozcan, C.C. et al. (2017), "Economic Freedom, Economic Growth and International Tourism for Post-Communist (Transition) Countries: A Panel Causality Analysis", Theoretical and Applied Economics, 2(611) 75-98.

Pesaran, M.H et al. (2008), “A Bias Adjusted LM Test of Error Cross Section Independence”, Econometrics Journal, 11, 105-127.

Pesaran, M.H. \& T. Yamagata (2008), “Testing Slope Homogeneity in Large Panels”, Journal of Econometrics, 142, 50-93.

Pesaran, M.H. (2004), “General Diagnostic Tests for Cross Section Dependence in Panels”, Cambridge Working Papers in Economics, 435, 1-39.

Pesaran, M.H. (2007), “A Simple Panel Unit Root Test in the Presence of Cross-Section Dependence", Journal of Applied Econometrics, 22, 265-312.

Sul, D. et al. (2005), "Prewhitening Bias in HAC Estimation", Oxford Bulletin of Economics and Statistics, 67, 517-546.

Toda, H.Y. \& T. Yamamoto (1995), "Statistical Inference in Vector Autoregressions with Possibly Integrated Processes", Journal of Econometrics, 66, 225-250.

Westerlund, J. \& D.L. Edgerton (2007), “A Panel Bootstrap Cointegration Test”, Ecomonic Letters, 97, 185-190.

Westerlund, J. (2007), "Testing for Error Correction in Panel Data”, Oxfor Bulletin of Economics and Statistics, 69(6), 709-748.

Yücesan, M. \& O. YağıŞ (2020), "Ekonomik Özgürlüğe Etki Eden Faktörler: Yükselen Piyasa Ekonomileri İçin Panel Veri Analizi”, Çankırı Karatekin Üniversitesi İktisadi ve İdari Bilimler Fakültesi Dergisi, 10(2), 691-711. 
Sökmen, F.Ş. \& S. Yaman \& M.B. Tunçel (2021), "Piyasa Güven Endeksi ile Finansal Yatırım Araçları Arasındaki İlişki: BRICS ve MIST Ülkeleri Üzerine Bir Araştırma”, Sosyoekonomi, 29(50), 361-386.

\section{Ekler}

Ek: 1

BCI ve INDEX Değişkenleri Arasındaki Asimetrik Nedensellik İliş̧kisi

\begin{tabular}{|c|c|c|c|c|c|c|c|c|}
\hline & \multicolumn{2}{|c|}{$\mathrm{BCI}^{+} \rightarrow \mathrm{INDEX}^{+}$} & \multicolumn{2}{|c|}{$\mathrm{BCI}^{+} \rightarrow \mathrm{INDEX}^{-}$} & \multicolumn{2}{|c|}{$\mathrm{BCI}^{-} \rightarrow \mathrm{INDEX}^{*}$} & \multicolumn{2}{|c|}{$\mathrm{BCI}^{-} \rightarrow \mathrm{INDEX}^{+}$} \\
\hline & MWALD & Olasılık & MWALD & Olasılık & MWALD & Olasılık & MWALD & Olasılık \\
\hline Panel & 36,440 & 0,006 **** & 22,831 & 0,197 & 44,113 & $0,001 * * *$ & 38,669 & 0,003 *** \\
\hline BRA & 16,436 & 0,001 *** & 14,291 & $0,074 *$ & 11,336 & $0,079 *$ & 17,416 & $0,026^{* *}$ \\
\hline RUS & 4,362 & 0,886 & 21,649 & $0,027 * *$ & 25,486 & $0,004 * * *$ & 16,605 & 0,120 \\
\hline IND & 3,579 & 0,612 & 8,231 & 0,767 & 26,060 & $0,011 * *$ & 23,263 & $0,026^{* * *}$ \\
\hline CHN & 0,464 & 0,927 & 2,778 & 0,427 & 2,354 & 0,502 & 2,098 & 0,552 \\
\hline ZAF & 0,625 & 0,891 & 6,653 & 0,880 & 10,612 & 0,389 & 16,394 & 0,174 \\
\hline MEX & 4,823 & 0,185 & 6,467 & 0,167 & 0,087 & 0,957 & 11,344 & $0,023^{* *}$ \\
\hline IDN & 34,685 & $0,001 * * *$ & 13,393 & 0,341 & 7,092 & 0,131 & 12,354 & 0,418 \\
\hline KOR & 1,575 & 0,455 & 8,400 & 0,753 & 24,864 & $0,010 * *$ & 17,773 & 0,123 \\
\hline \multirow[t]{3}{*}{ TUR } & 2,886 & 0,557 & 1,643 & 0,440 & 2,385 & 0,303 & 1,628 & 0,443 \\
\hline & \multicolumn{2}{|c|}{ INDEX $^{+} \rightarrow$ BCI $^{+}$} & \multicolumn{2}{|c|}{ INDEX $^{+} \rightarrow$ BCI $^{-}$} & \multicolumn{2}{|c|}{ INDEX $^{-} \rightarrow$ BCI $^{-}$} & \multicolumn{2}{|c|}{ INDEX $^{-} \rightarrow$ BCI $^{+}$} \\
\hline & MWALD & Olasılık & MWALD & Olasılık & MWALD & Olasılık & MWALD & Olasılık \\
\hline Panel & 36,650 & $0,006^{* * * *}$ & 36,306 & $0,006 * * *$ & 17,815 & 0,468 & 19,804 & 0,344 \\
\hline BRA & 4,245 & 0,236 & 21,465 & $0,000 * * *$ & 11,256 & $0,081 *$ & 3,092 & 0,378 \\
\hline RUS & 25,319 & 0,003 *** & 1,279 & 0,258 & 12,844 & 0,133 & 0,008 & 0,929 \\
\hline IND & 10,976 & $0,052^{*}$ & 3,208 & 0,361 & 14,718 & 0,257 & 1,019 & 0,797 \\
\hline CHN & 3,467 & 0,325 & 4,621 & 0,202 & 1,763 & 0,623 & 4,487 & 0,213 \\
\hline ZAF & 2,436 & 0,487 & 2,173 & 0,537 & 5,678 & 0,842 & 1,110 & 0,775 \\
\hline MEX & 7,260 & 0,064 & 3,880 & 0,868 & 0,919 & 0,631 & 13,560 & $0,094 *$ \\
\hline IDN & 5,372 & 0,944 & 16,364 & $0,060 *$ & 7,606 & 0,107 & 6,866 & 0,651 \\
\hline KOR & 3,527 & 0,171 & 2,708 & 0,439 & 5,773 & 0,888 & 5,256 & 0,154 \\
\hline TUR & 5,891 & 0,207 & 1,526 & 0,676 & 0,233 & 0,890 & 5,931 & 0,115 \\
\hline
\end{tabular}

Ek: 2

\section{BCI ve CUR Değiş̧kenleri Arasındaki Asimetrik Nedensellik İlişsisi}

\begin{tabular}{|c|c|c|c|c|c|c|c|c|}
\hline & \multicolumn{2}{|c|}{$\mathrm{BCI}^{+} \rightarrow \mathrm{CUR}^{+}$} & \multicolumn{2}{|c|}{$\mathrm{BCI}^{+} \rightarrow \mathrm{CUR}^{-}$} & \multicolumn{2}{|c|}{$\mathrm{BCI}^{-} \rightarrow \mathrm{CUR}^{-}$} & \multicolumn{2}{|c|}{$\mathrm{BCI}^{-} \rightarrow \mathrm{CUR}^{+}$} \\
\hline & MWALD & Olasılık & MWALD & Olasılık & MWALD & Olasılık & MWALD & Olasılık \\
\hline Panel & 24,397 & 0,142 & 13,908 & 0,735 & 15,935 & 0,597 & 33,137 & 0,016 ** \\
\hline BRA & 0,215 & 0,898 & 5,128 & 0,163 & 0,309 & 0,857 & 7,378 & $0,061^{*}$ \\
\hline RUS & 0,554 & 0,457 & 0,007 & 0,932 & 12,528 & 0,129 & 3,085 & 0,079 \\
\hline IND & 2,622 & 0,454 & 15,480 & 0,216 & 11,374 & 0,123 & 20,358 & $0,061^{*}$ \\
\hline CHN & 11,870 & $0,018 * *$ & 1,831 & 0,608 & 0,678 & 0,878 & 2,084 & 0,555 \\
\hline ZAF & 11,341 & 0,500 & 10,428 & 0,578 & 6,486 & 0,773 & 18,176 & 0,110 \\
\hline MEX & 4,668 & $0,097 *$ & 0,756 & 0,685 & 0,259 & 0,879 & 5,145 & $0,076^{*}$ \\
\hline IDN & 11,141 & $0,049 * *$ & 10,423 & 0,579 & 11,981 & 0,286 & 15,326 & 0,224 \\
\hline KOR & 0,972 & 0,808 & 1,949 & 0,999 & 12,918 & 0,375 & 13,898 & 0,239 \\
\hline \multirow[t]{3}{*}{ TUR } & 0,509 & 0,775 & 1,578 & 0,209 & 0,717 & 0,397 & 0,025 & 0,875 \\
\hline & \multicolumn{2}{|c|}{$\mathrm{CUR}^{+} \rightarrow \mathrm{BCI}^{+}$} & \multicolumn{2}{|c|}{$\mathrm{CUR}^{+} \rightarrow \mathrm{BCI}^{-}$} & \multicolumn{2}{|c|}{$\mathrm{CUR}^{-} \rightarrow \mathrm{BCI}^{-}$} & \multicolumn{2}{|c|}{$\mathrm{CUR}^{-} \rightarrow \mathrm{BCI}^{+}$} \\
\hline & MWALD & Olasılık & MWALD & Olasılık & MWALD & Olasılık & MWALD & Olasılık \\
\hline Panel & 79,449 & 0,000 **** & 46,629 & $0,000 * * *$ & 26,889 & $0,081 *$ & 24,655 & 0,135 \\
\hline BRA & 2,080 & 0,353 & 6,473 & $0,039 * *$ & 3,335 & 0,189 & 0,651 & 0,722 \\
\hline RUS & 5,984 & $0,014 * *$ & 0,000 & 0,989 & 12,801 & 0,119 & 0,282 & 0,596 \\
\hline IND & 13,790 & $0,003 * * *$ & 44,148 & $0,000 * * *$ & 15,123 & $0,034 * *$ & 9,212 & 0,685 \\
\hline CHN & 19,052 & $0,001 * * *$ & 13,610 & 0,192 & 5,075 & 0,166 & 22,068 & 0,015 ** \\
\hline ZAF & 57,831 & $0,000 * * *$ & 7,131 & 0,713 & 5,279 & 0,872 & 12,335 & 0,263 \\
\hline MEX & 0,533 & 0,766 & 2,399 & 0,494 & 5,045 & $0,080^{*}$ & 1,364 & 0,714 \\
\hline IDN & 2,717 & 0,744 & 21,107 & $0,007 * * *$ & 10,902 & 0,365 & 14,635 & 0,067 * \\
\hline KOR & 9,347 & $0,025 * *$ & 0,358 & 0,836 & 8,777 & 0,722 & 2,590 & 0,274 \\
\hline TUR & 1,161 & 0,560 & 3,317 & 0,345 & 0,259 & 0,611 & 3,690 & 0,297 \\
\hline
\end{tabular}


Sökmen, F.Ş. \& S. Yaman \& M.B. Tunçel (2021), "Piyasa Güven Endeksi ile Finansal Yatırım Araçları Arasındaki İlişki: BRICS ve MIST Ülkeleri Üzerine Bir Araştırma”, Sosyoekonomi, 29(50), 361-386.

Ek: 3

BCI ve BOND Değişkenleri Arasındaki Asimetrik Nedensellik İlişkisi

\begin{tabular}{|c|c|c|c|c|c|c|c|c|}
\hline & \multicolumn{2}{|c|}{$\mathrm{BCI}^{+} \rightarrow \mathrm{BOND}^{+}$} & \multicolumn{2}{|c|}{$\mathrm{BCI}^{+} \rightarrow$ BOND $^{-}$} & \multicolumn{2}{|c|}{$\mathrm{BCI}^{-} \rightarrow \mathrm{BOND}^{-}$} & \multicolumn{2}{|c|}{$\mathrm{BCI}^{-} \rightarrow \mathrm{BOND}^{+}$} \\
\hline & MWALD & Olasılık & MWALD & Olasılık & MWALD & Olasılık & MWALD & Olasılık \\
\hline Panel & 20,016 & 0,332 & 29,746 & $0,040^{* *}$ & 15,080 & 0,656 & 33,223 & $0,016^{* *}$ \\
\hline BRA & 2,484 & 0,478 & 1,832 & 0,400 & 1,298 & 0,523 & 0,267 & 0,875 \\
\hline RUS & 0,021 & 0,884 & 0,706 & 0,703 & 3,107 & 0,375 & 1,531 & 0,465 \\
\hline IND & 1,483 & 0,476 & 19,752 & $0,006^{* * * *}$ & 3,572 & 0,828 & 10,323 & 0,171 \\
\hline CHN & 7,711 & 0,103 & 7,873 & $0,049 * *$ & 1,748 & 0,782 & 3,766 & 0,288 \\
\hline ZAF & 7,075 & 0,529 & 7,237 & 0,703 & 4,312 & 0,932 & 8,240 & 0,605 \\
\hline MEX & 3,513 & 0,173 & 2,626 & 0,269 & 0,545 & 0,909 & 0,004 & 0,998 \\
\hline IDN & 8,467 & $0,037 * *$ & 12,084 & 0,439 & 21,866 & $0,039 * *$ & 42,348 & $0,000 * * *$ \\
\hline KOR & 0,719 & 0,698 & 7,274 & 0,776 & 3,301 & 0,192 & 7,271 & 0,777 \\
\hline \multirow[t]{3}{*}{ TUR } & 0,173 & 0,917 & 3,425 & $0,064 *$ & 0,835 & 0,659 & 1,485 & 0,223 \\
\hline & \multicolumn{2}{|c|}{ BOND $^{+} \rightarrow$ BCI $^{+}$} & \multicolumn{2}{|c|}{ BOND $^{+} \rightarrow$ BCI $^{-}$} & \multicolumn{2}{|c|}{ BOND $^{-} \rightarrow \mathrm{BCI}^{-}$} & \multicolumn{2}{|c|}{ BOND $^{-} \rightarrow$ BCI $^{+}$} \\
\hline & MWALD & Olasılık & MWALD & Olasılık & MWALD & Olasılık & MWALD & Olasılık \\
\hline Panel & 22,286 & 0,220 & 33,162 & $0,016^{* * *}$ & 27,907 & $0,063^{*}$ & 19,085 & 0,387 \\
\hline BRA & 16,117 & $0,001 * * *$ & 1,048 & 0,592 & 0,744 & 0,689 & 4,140 & 0,126 \\
\hline RUS & 0,315 & 0,575 & 0,859 & 0,354 & 6,019 & 0,111 & 1,633 & 0,201 \\
\hline IND & 1,324 & 0,516 & 17,609 & $0,091 *$ & 20,785 & $0,004^{* * * *}$ & 16,011 & 0,141 \\
\hline CHN & 1,315 & 0,859 & 2,291 & 0,682 & 3,318 & 0,506 & 9,797 & $0,044 * *$ \\
\hline ZAF & 5,944 & 0,654 & 6,046 & 0,109 & 3,894 & 0,952 & 0,212 & 0,976 \\
\hline MEX & 0,327 & 0,849 & 4,792 & 0,188 & 1,905 & 0,592 & 1,742 & 0,628 \\
\hline IDN & 2,563 & 0,464 & 25,514 & $0,013 * *$ & 16,146 & 0,185 & 6,501 & 0,889 \\
\hline KOR & 1,876 & 0,392 & 0,268 & 0,875 & 3,190 & 0,203 & 0,318 & 0,853 \\
\hline TUR & 1,286 & 0,526 & 23,839 & $0,021 * *$ & 2,693 & 0,260 & 4,045 & 0,983 \\
\hline
\end{tabular}

Ek: 4

BCI ve GOLD Değişkenleri Arasındaki Asimetrik Nedensellik İlişkisi

\begin{tabular}{|c|c|c|c|c|c|c|c|c|}
\hline & \multicolumn{2}{|c|}{$\mathrm{BCI}^{+} \rightarrow \mathrm{GOLD}^{+}$} & \multicolumn{2}{|c|}{ BCI $^{+} \rightarrow$ GOLD $^{-}$} & \multicolumn{2}{|c|}{$\mathrm{BCI}^{-} \rightarrow \mathrm{GOLD}^{-}$} & \multicolumn{2}{|c|}{$\mathrm{BCI}^{-} \rightarrow \mathrm{GOLD}^{+}$} \\
\hline & MWALD & Olasılık & MWALD & Olasılık & MWALD & Olasılık & MWALD & Olasılık \\
\hline Panel & 31,568 & $0,025 * *$ & 38,385 & $0,003^{* * * *}$ & 21,386 & 0,260 & 56,655 & 0,000 \\
\hline BRA & 2,440 & 0,295 & 16,701 & 0,161 & 1,671 & 0,434 & 38,998 & 0,000 \\
\hline RUS & 1,714 & 0,634 & 0,755 & 0,686 & 0,511 & 0,744 & 1,038 & 0,595 \\
\hline IND & 6,899 & 0,228 & 11,286 & 0,505 & 10,839 & 0,543 & 13,052 & 0,365 \\
\hline CHN & 10,658 & $0,014 * *$ & 16,782 & $0,001 * * *$ & 19,656 & $0,074^{*}$ & 4,274 & 0,233 \\
\hline ZAF & 28,200 & $0,005 * * *$ & 12,928 & 0,298 & 9,837 & 0,630 & 23,775 & 0,014 \\
\hline MEX & 1,545 & 0,672 & 2,002 & 0,572 & 0,063 & 0,969 & 0,880 & 0,830 \\
\hline IDN & 5,239 & 0,155 & 15,849 & $0,007 * * *$ & 3,375 & 0,497 & 18,527 & 0,002 \\
\hline KOR & 9,104 & 0,694 & 9,672 & 0,560 & 20,616 & $0,038^{* *}$ & 17,439 & 0,096 \\
\hline \multirow[t]{3}{*}{ TUR } & 1,700 & 0,637 & 5,286 & 0,152 & 3,824 & 0,148 & 8,518 & 0,036 \\
\hline & \multicolumn{2}{|c|}{ GOLD $^{+} \rightarrow \mathrm{BCI}^{+}$} & \multicolumn{2}{|c|}{ GOLD $^{+} \rightarrow$ BCI $^{-}$} & \multicolumn{2}{|c|}{ GOLD $^{-} \rightarrow \mathrm{BCI}^{-}$} & \multicolumn{2}{|c|}{ GOLD $^{-} \rightarrow \mathbf{B C I}^{+}$} \\
\hline & MWALD & Olasılık & MWALD & Olasılık & MWALD & Olasılık & MWALD & Olasılık \\
\hline Panel & 31,233 & $0,027 * *$ & 21,998 & 0,232 & 31,765 & $0,023 * *$ & 20,915 & 0,284 \\
\hline BRA & 3,243 & 0,198 & 2,446 & 0,294 & 0,447 & 0,800 & 0,188 & 0,910 \\
\hline RUS & 2,913 & 0,405 & 1,118 & 0,572 & 2,677 & 0,262 & 1,845 & 0,398 \\
\hline IND & 4,259 & 0,513 & 18,176 & 0,110 & 16,703 & 0,161 & 11,771 & 0,464 \\
\hline CHN & 2,880 & 0,411 & 0,645 & 0,724 & 37,827 & $0,000 * * *$ & 1,554 & 0,460 \\
\hline ZAF & 18,595 & $0,099^{*}$ & 15,893 & 0,145 & 8,004 & 0,785 & 7,765 & 0,734 \\
\hline MEX & 0,621 & 0,892 & 3,454 & 0,178 & 3,861 & 0,145 & 0,46 & 0,800 \\
\hline IDN & 4,091 & 0,252 & 4,071 & 0,254 & 2,330 & 0,675 & 8,499 & $0,037 * *$ \\
\hline KOR & 31,031 & $0,001 * * *$ & 2,293 & 0,318 & 12,436 & 0,332 & 5,727 & $0,057^{*}$ \\
\hline TUR & 3,484 & 0,323 & 1,034 & 0,569 & 0,221 & 0,896 & 2,393 & 0,302 \\
\hline
\end{tabular}

